\title{
CANADIAN AND ALBERTA STATUTES DEALING WITH LAND TITLES AND REAL PROPERTY
}

\section{E. F. GAMACHE*}

This is an index and a summary of selected sections from the Canadian Statutes (up to and including the 1965 Statutes) and the Alberta Statutes (up to and including the 1966 Statutes) dealing primarily with Land Titles practice, and to a lesser extent with Real Property generally.

Many sections have been omitted because of lack of space or where the whole Act was relevant such as The Land Titles Act, Condominium Property Act, Mechanics' Lien Act, Dower Act, etc.

This index and summary intend to fulfill the following purposes:

(1) to enable the conveyancer to locate sections seldom used;

(2) to collect in one place sections that are widely scattered in the Canadian and Alberta Statutes;

(3) to be used as a check list before closing transactions.

PART I contains the Index and Summary from the Canadian Statutes and PART II for the Alberta Statutes, in alphabetical order.

Attention is directed to an article in (1964) 3 Alberta L. Rev. 262"The Introduction of English Law in Alberta" by J. E. Côté. There is a table of English Statutes in force in Canada at page 278.

The relevancy of the sections selected reflects the views of the writer and not the views of either the Land Titles Office or the Attorney General's Department for the Province of Alberta. 


\section{NDEX}

\section{Part I-STATUTES OF CANADA}

Alberta Act, 1905 S.C. c. 3; 1955 R.S.A. Vol. 5 page 5671 513

Alberta Natural Resources Act. 1930 S.C. c 3; 1930 S.A. c. 21

1955 R.S.A. Vol. 5. page 5691.

Bank Act, 1953-54 S.C. c. 48.

Bankruptcy Act, 1952 R.S.C. c. 14.

Canada Lands Surveys Act 1951 (2nd Session) S.C. c. 4; 1952 R.S.C. c. 26.

Canadian National Railways Act, 1955 S.C. c. 29

Central Mortgage \& Housing Corporation Act, 1952 R.S.C. c. 46.

Canada Corporations Act, 1952 R.S.C. c. 53.

Dominion Succession Duty Act, 1952 R.S.C. c. 89.

Escheats Act, 1952 R.S.C. c. 97.

Estate Tax Act, 1958 S.C. c. 29.

Exchequer Court Act, 1952 R.S.C. c. 98

Expropriation Act, 1952 R.S.C. c. 106.

Farm Credit Act, 1959 S.C. c. 43.

Farm Improvement Loans Act, 1952 R.S.C. c. 110.

Farmer's Creditors Arrangement Act, 1952 R.S.C. c. 111.

Indian Act, 1952 R.S.C. c. 149.

Interest Act, 1952 R.S.C. c. 156.

Lord's Day Act, 1952 R.S.C. c. 171.

National Energy Board Act, 1959 S.C. c. 46.

National Housing Act, 1953-54 S.C. c. 23

National Parks Act, 1952 R.S.C. c. 189.

Navigable Waters Protection Act, 1952 R.S.C. c. 193.

Public Lands Grants Act, 1952 R.S.C. c. 224.

Railway Act, 1952 R.S.C. c. 234.

Saskatchewan and Alberta Roads Act, 1927 R.S.C. c. 180.

Veterans Land Act, 1952 R.S.C. c. 280.

Winding-up Act, 1952 R.S.C. c. 296.

\section{Part II-STATUTES OF ALBERTA}

Agricultural Relief Advances Act, 1955 R.S.A. c. 7

Alberta Natural Resources Act, 1930 S.A. c. 21.

Cemeteries Act. 1960 S.A. c. 12.

City Act, 1955, R.S.A. c. 42.

Clay and Marl Act, 1961 S.A. c. 14.

Commissioner for Oaths Act, 1955 R.S.A. c. 50 .

Communal Property Act, 1955 R.S.A. c. 52

Companies Act, 1955 R.S.A. c. 53.

Condominium Property Act, 1966 S.A. c. 19.

County Act, 1955 R.S.A. c. 64 .

Devolution of Real Property Act, 1955 R.S.A. c. 83.

Domestic Relations Act, 1955 R.S.A. c. 89

Dower Act, 1955 R.S.A. c. 90.

Drainage Districts Act, 1955 R.S.A. c. 91.

Evidence Act, 1955 R.S.A. c. 102.

Execution Creditors Act, 1955 R.S.A. c. 103

Exemptions Act, 1955 R.S.A. c. 104.

Expropriation Procedure Act, 1961, S.A. c. 30.

Family Relief Act, 1955 R.S.A. c. 109.

Gas Utility Act, 1960 S.A. c. 37.

Hospitals Act, 1961 S.A. c. 36.

Improvement Districts Act, 1965 S.A. c. 39.

Infants Act, 1955 R.S.A. c. 158

Intestate Succession Act. 1955 R.S.A. c. 161.

Irrigation Districts Act, 1955 R.S.A. c. 162.

Judicature Act, 1955 R.S.A. c. 164. .

Juvenile Court Act, 1955 R.S.A. c. 166.

Land Surveyors Act, 1965 S.A. c. 44

Land Titles Act, 1955 R.S.A. c. 170. 
Land Titles Clarification Act, 1956 S.A. c. 26.

Landlord and Tenant Act, 1964 S.A. c. 43.

Landlord's Rights in Bankruptcy Act, 1955 R.S.A. c. 171.

Lands and Forests Act, Department of 1955 R.S.A. c. 172.

Legal Profession Act, 1966 S.A. c. 46 523

Limitation of Actions Act, 1955 R.S.A. c. 177.

Line Fence Act, 1955 R.S.A. c. 178.

Local Authorities Board Act, 1961 S.A. c. 46

Local Tax Arrears Consolidation Act, 1955 R.S.A. c. 185.

Maintenance Order Act, 1955 R.S.A. c. 188.

Married Womens' Act, 1955 R.S.A. c. 193.

Mechanics' Lien Act, 1960 S.A. c. 64.

Mentally Incapacitated Persons Act, 1955 R.S.A. c. 201

Metis Betterment Act, 1955 R.S.A. c. 202

Mineral Declaratory Act, 1961 S.A. c. 48.

Mineral Interests Compensation Act, 1958 S.A. c. 43.

Mineral Taxation Act, 1955 R.S.A. c. 203.

Mineral Titles Clarification Act, 1956 S.A. c. 32

Mineral Titles Redemption Act, 1958 S.A. c. 44

Mines and Minerals Act, 1962 S.A. c. 49.

Municipal Districts Act, 1955 R.S.A. c. 215.

Municipal Districts Act, 1959 S.A. c. 55.

Municipal Improvements Assistance (Alberta) Act, 1955 R.S.A. c. 217.

Municipal and School Administration Act, 1962 S.A. c. 54

Names of Homes Act, 1955 R.S.A. c. 219.

National Housing Loans Act (Alberta), 1955 R.S.A. c. 220.

New Towns Act, 1956 S.A. c. 39.

Notaries Public Act, 1955 R.S.A. c. 222.

Noxious Weeds Act, 1955 R.S.A. c. 223.

Oil and Gas Conservation Act, 1957 S.A. c. 63.

Partnership Act, 1955 R.S.A. c. 230

Proceedings Against the Crown Act, S.A. c. 63.

Pipe Line Act 1958, 1958 S.A. c. 58.

Planning Act, 1963 S.A. c. 43

Private Ditches Act, 1955 R.S.A. c. 241

Public Highways Development Act, 1966 S.A. c. 79.

Public Lands Act, 1966 S.A. c. 80.

Public Trustee Act, 1955 R.S.A. c. 266

Public Utilities Board Act, 1960 S.A. c. 85.

Public Welfare Act, 1955 R.S.A. c. 268

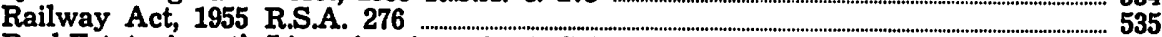

Real Estate Agent's Licensing Act, 1955 R.S.A. c. 279. .

Religious Societies Lands Act, 1955 R.S.A. c. 285

Right of Entry Arbitration Act, 1955 R.S.A. c. 290.

Rural Electrification Revolving Fund Act, 1955 R.S.A. c. 291

Rules of the Supreme Court of Alberta, Consolidated-1962 ……................................... 538

Sand and Gravel Act, 1955 R.S.A. c. 296. .

School Act, 1955 R.S.A. c. 297.

Securities Act 1955, 1955 S.A. c. 64

Seizures Act, 1955 R.S.A. c. 307.

Societies Act, 1955 R.S.A. c. 315

Special Areas Act, 1964 S.A. c. 87

Succession Duty Act, 1955 R.S.A. c. 324

Alberta Surveys Act, 1955 R.S.A. c. 327

Tax Recovery Act, 1955 R.S.A. c. 334

Alberta Government Telephones Act, 1958 S.A. c. 85.

Temporary Restriction on Alienation of Mines and Minerals Act, 1955 S.A. c. 67 ..... 544

Town and Village Act, 1955 R.S.A. c. 338.

Transfer and Descent of Land Act, 1955 R.S.A. c. 342

Treasury Branches Act, 1955 R.S.A. c. 344. .

Trustee Act, 1955 R.S.A. c. 346

Ultimate Heir Act, 1955 R.S.A. c. 348.

Unconscionable Transactions Act, S.A. 1964 c. 99.

Urban Mining Operations Act, 1955 R.S.A. c. 353.

Utilization of Lands and Forest Act, 1955 R.S.A. c. 354

Water, Gas, Electric and Telephone Companies Act, R.S.A. 1955 c. 361.

Water Resources Act, 1955 R.S.A. c. 362.

Water Users' Districts Act, 1955 R.S.A. c. 363

Wills Act, 1960 S.A. c. 118.

Workmen's Compensation Act, 1955 R.S.A. c. 370. 


\section{PART I-STATUTES OF CANADA}

Statute

Alberta Act.

1905 S.C. c. 3.

1955 R.S.A. Vol. 5.

page 5671 .

\section{Alberta Natural Resources Act. 1930 S.C. c. 3. \\ 1930 S.C. c. 21. \\ 1955 R.S.A. Vol. 5. page 5691 .}

Bank Act. 1953-54 S.C. c. 48.

Bankruptcy Act. 1952 R.S.C. c. 14.

\section{Section Number and Summary}

s. 21-All crown lands, mines, minerals and royalties incident thereto ... shall continue to be vested in the Crown and administered by the Government of Canada, etc.

\author{
Enacts transfer of further rights from Crown Dominion to \\ Crown Province. \\ Agreement covers public lands, school lands, water, Indian \\ Reserves, Soldier Settlement Lands, National Parks, General \\ Reservation to Canada.
}

s. 75 (2) (d)-Bank shall not directly or indirectly lend money or make advances upon the security of real or immovable property.

s. 75 (5)-Bank can acquire securities issued or guaranteed by any property.

s. 78 (1)-Bank may subsequently take etc. security of any kind etc. upon real property.

s. 81-Bank may acquire and hold real and immovable property under certain conditions.

s. 82 (1)-Loans on hydrocarbons.

s. 82 (5)-Bank has priority if there is registered in land titles office, original of the instrument, certified copy of the instrument or a caveat.

s. 89 (2)-Security under Sec. 88 (1) (c), (d), (e), (g), must be registered in Land Titles Office.

s. 2 (o)-Definition of property.

s. 2 ( $r$ )-Definition of secured creditor.

s. 8 (11)-Trustee may divest himself of any real or immovable property of bankrupt by notice to registrar of Land Titles.

s. 10 (1) (a)-Power of trustee to sell all or part of property. s. 10 (1) (b)-Power of trustee to lease any real or immovable property.

s. 41 (1)-Every receiving order and every assignment takes precedence except executed payments to creditors or agent and except rights of a secured creditor.

s. 41 (5)-Receiving order or an assignment filed with receiver subject to rights of secured creditor shall forthwith pass to and vest property in the trustee, and in any case of change of trustee, the property shall pass from trustee to trustee without any conveyance assignment or transfer.

s. 43 (1)-Receiving order may be registered in Land Titles Office.

s. 43 (2)-Trustee entitled to be registered as owner free of all encumbrances or charges mentioned in $\mathrm{s}$. 41 (1).

s. 43 (3)-Caveat may be registered where bankrupt believed to have an interest or where receiving order or assignment has not been registered.

s. 44-Bona fide purchaser for value not deprived unless receiving order or assignment has been registered against the property in the proper office.

s. 53-Sale by trustee vests in purchaser all legal and equitable estate of the bankrupt.

Canada Lands Surveys s. 31-"Public Lands" means any land belonging to Her MaAct. jesty in Right of Canada or of which the Government has 1951 (2nd Sess.) S.C. c. 4 1952 R.S.C. c. 26. Northwest Territories or in any National Park of Canada and any lands that are surrendered lands or reserves as defined in the Indian Act. 
Canadian National Railways Act. 1955 S.C. c. 29.

Central Mortgage and Housing Corporation Act.

1952 R.S.C. c. 46.

Canada Corporations Act.

1952 R.S.C. c. 53.

Dominion Succession Duty Act.

1952 R.S.C. c. 89.

Escheats Act. 1952 R.S.C. c. 97.

Estate Tax Act. 1958 S.C. c. 29. s. 17-The Expropriation Act applies subject to certain conditions.

s. 18 (1)-The railway or other transportation works are declared to be works for the general advantage of Canada.

s. 2 (h)- "Mortgage" includes a hypothec and an agreement for sale.

s. 5 (3)-Property acquired by the Corporaton is the property of Her Majesty and title thereto may be vested in the name of Her Majesty or in the name of the Corporation.

s. 29 (1) (a)-Corporation may realize upon any mortgage \&c, take title to etc. and may sell or dispose of such property. s. 29 (1) (b)-Corporation may hold property for its own use etc.

s. 29 (2)-Where title to real or immovable property becomes vested in the name of the Corporation or of Her Majesty, the Corporation may pay to a municipal or other taxing authority the amount equivalent to the taxes etc.

s. 14 (1) (b), (i), (k), (m), (s)-Power of company over real property.

s. 66 (1)-Copies of certain mortgages to be delivered to Secretary of State.

s. 66 (5) - Secretary of State to keep register of mortgages for each company.

s. 66 (11)-Company to keep a copy at head office of every instrument creating any mortgage or charge.

s. 68-Secretary of State to provide memorandum of satisfaction when mortgage has been paid.

s. 70-Every company to keep a register of mortgages and charges.

s. 148 (b)-“Real Property" or "land" includes messuages, lands, tenements and hereditaments of any tenure and all immovable property of any kind.

s. 151 (1)-Powers of a Company incorporated under a special Act to deal with real property.

s. 2 (k)- "Property" defined.

s. 2 (n)- "Successor" defined.

s. 13-Liability of successor.

s. 25 (3)-Lien of Crown on land or mortgage or charge upon death of a predecossor dying domiciled outside of Canada.

s. 25 (4)-Deputy Minister \&c may cause to be registered a caution in land titles office for succession duty.

NOTE: This act does not apply where deceased died on or after January 1st, 1959. Estate Tax Act takes effect after that date.

s. 2-Where Her Majesty the Queen in Right of Canada is entitled to land or other real or personal property by reason of person dying intestate and without lawful heirs or by reason of any corporation, association or society having been finally dissolved or wound up or having ceased to exist, the Attorney General of Canada may cause possession thereof to be taken in the name of Her Majesty etc.

s. 5-No action \&c \&c shall be brought after 5 years from date of death of person last ceased or 5 years from date of dissolution or winding up or ceasing to exist in case of corporation \&c.

s. 43 (1)-Any amount payable as a tax ... by a person as the successor to any property passing on the death of a deceased shall .... be and continue to be for as long as that amount or any part thereof remains unpaid a lien upon such estate or interest in favour of Her Majesty; and the Minister may cause to be registered in such office a caution ...

s. 43 (2) - ... the consent of the Minister under Sec. 47 . . shall be deemed to discharge such lien... s. 58 (1) ( $r$-Definition of "Successor".

NOTE-This Act comes into force on estates where deceased died on or after 1st of January, 1959. 
Exchequer Court Act. 1952 R.S.C. c. 98.

Expropriation Act. 1952 R.S.C. c. 106.

Farm Credit Act. 1959 S.C. c. 43.

Farm Improvement Loans Act. 1952 R.S.C. c. 110.

Farmer's Creditors Arrangement Act. 1952 R.S.C. c. 111.

Indian Act. 1952 R.S.C. c. 149.

Interest Act. 1952 R.S.C. c. 156.

Lord's Day Act. 1952 R.S.C. c. 171.

National Energy

Board Act.

1959 S.C. c. 46. s. 56-Writs of Execution against real or personal property \&c shall be executed in the same manner as similar writs, issued out of the superior courts of the province in which the property is situated, are, by the law of the province, required to be executed.

s. 74 (1)-The process of the court shall be directed to the sheriff of any county or other judicial division into which any province is subdivided.

SPECIAL NOTE-Exchequer Court General Rules and Orders (21st April, 1931 and amendments) provide in Rule 202 that writ of execution (fieri facias) shall remain in force for 5 years from its issue unless renewed \&c.

Contains 36 sections most of which deal with Real Property and Land Titles procedure.

s. 10 (1)-The Corporation is for all purposes of this Act an agent of Her Majesty, and its powers under this Act may be exercised only as an agent of Her Majesty.

s. 17-The Corporation may pay to a municipal or other taxing authority an amount equivalent to the taxes that might be levied \&c.

s. 30 (1)-The Farm Credit Corporation is hereby declared to be the successor to the Canadian Farm Loan Board, \&c.

S. 7 (2) -Security taken by a Bank under Farm Improvement Loans Act same as additional security under Sec. 78 Bank Act.

s. 10 (1) On a proposal being filled the property of the farmer shall be deemed to be under the authority of the court etc. s. 10 (2)-No farmer who has filed a proposal has capacity except by leave of the court to sell or otherwise dispose of property etc.

s. 31- Whenever a composition etc. has been approved, court may order farmer or any creditor to execute or discharge any mortgage, conveyance or other instrument necessary to give effect thereto.

s. 42 (1)-Where rate of interest exceeding $7 \%$ is stipulated for in any mortgage of farm real estate, a tender of amount owing on mortgage and three months interest in lieu of notice reduces interest to $5 \%$ thereafter.

s. 88 (1) The real property of an Indian or a band situated on a reserve is not subject to charge, pledge, mortgage, attachment, lien, seizure, distress or execution in favour or at the instance of any person other than an Indian.

s. 89 (2)-Transfer of title to land on a reserve void unless consented to by Minister, or is entered into between members of a band.

s. 6-Mortgages providing for blended payments of principal and interest shall contain a statement showing amount of principal and the rate of interest.

s. 10 (1)-Mortgages whose term is greater than 5 years can be repaid after expiration of five years upon tender of amount due for principal and interest together with 3 months interest in lieu of notice.

s. 10 (2)-Sec. 10 (1) not applicable to mortgage by a joint stock company.

s. 4-It is not lawful for any person on the Lord's Day . . to sell or offer for sale or purchase any ... real estate.

s. 34 (1)-Every registrar of deeds shall receive and preserve in his office all plans etc.

s. 69-A company is not entitled to mines, ores, metals . . . in or under lands purchased by it.

s. $73-$ Subject to section 74 the lands that may, without the consent of the owner, be taken for the right of way of a pipeline shall not exceed 60 feet in breadth. 
National Housing Act. s. 2 (27)-"Mortgage" includes hypothec and an assignment of 1953-54 S.C. c. 23.

National Parks Act. 1952 R.S.C. c. 189.

Navigable Waters Protection Act. 1952 R.S.C. c. 193.

Public Lands Grant Act. 1952 R.S.C. c. 224.

Railway Act. 1952 R.S.C. c. 234.

Saskatchewan and Alberta Roads Act. 1927 R.S.C. c. 180.

Veterans Land Act. 1952 R.S.C. c. 280.

Winding-up Act. 1952 R.S.C. c. 296. or a mortgage on the leasehold interest of a lessee. s. 2 (36)- "Title" in relation to a loan secured by a mortgage on a long-term lease means the entire interest of the lessee. s. 5-Every right or obligation acquired or incurred by the Corporation ... is a right or obligation of Her Majesty. s. 37 (6)-The Corporation may pay to a municipality an amount equivalent to the taxes etc.

s. 6(2) - . . lands sold, leased or otherwise disposed of, shall still be part of the Park ... and if any such lands cease to be used for the purpose for which they were so sold, leased or otherwise disposed of, they thereupon revert to the Crown. s. 7 (g)-The Governor in Council may ... make regulations for the granting of leases, etc.

s. 7 (1)-The local authorities or person proposing to construct any work in navigable waters . . . may deposit plans and a description of the proposed site with the Minister and a duplicate of each in the office of the Registrar of Deeds, etc. s. 7 (2)-Where there is no registrar of deeds ... shall be deposited in nearest Land Titles Office etc.

Whole-All sections relevant to grants from Her Majesty in Right of Canada.

s. 169-The Company shall not ... commence the construction ... until the plan ... thereof deposited with the registrar of deeds etc.

s. 198 (1)-The Company is not, unless the same have been expressly purchased entitled to any mines, ores, metals etc.

s. 7-All road allowances ... shall be vested in the Crown in the Right of the Province ....

s. 8- Nothing herein shall be construed to vest in the Crown in the Right of the Province any mines or minerals under any part of any road \&c.

s. 5 (1)-For the purposes of acquiring, holding, conveying ... the Director is a corporation sole .... and as such is the agent of Her Majesty in Right of Canada.

s. 5 (3)-All conveyances from the Director constitute new titles to the land conveyed and have the same and as full effect as grants from the Crown of previously ungranted Crown Lands.

s. 12-Every veteran holding or occupying land sold by the Director shall until the Director grants or conveys the land to him be deemed a tenant at will.

s. 30- . . The Mechanic's Lien laws, or other lien laws or the dower of homestead laws of any province do not extend or apply in priority or prejudice to the Directors interest in lands ...

s. 31-Upon the appointment of the liquidator, all the powers of the directors shall cease etc.

s. 33-The liquidator upon his appointment shall take into his custody or under his control, all the property etc.

s. 35 (1)-The liquidator may, with the approval of the Court $\ldots$ (c) sell the real ... property ... (g) raise upon the security of the assets of the company .... any requisite sums ... s. 122-If any person claims any lien on papers, deeds, writings . . . such production is without prejudice to such lien ... 


\section{PART II-STATUTES OF ALBERTA}

Agricultural Relief Advances Act. 1955 R.S.A. c. 7.

\begin{abstract}
Alberta Natural Resources Act. 1930 S.A. c. 21.
\end{abstract}

Cemeteries Act. 1960 S.A. c. 12.

City Act.

1955 R.S.A. c. 42.

Clay and Marl Act. 1961 S.A. c. 14.

Commissioner for Oaths Act. 1955 R.S.A. c. 50. s. 13 (3) (b) (ii) - ... the municipality shall take from the recipient thereof a written agreement in form $B$ in the schedule for a charge upon the interest of the recipient in the land in respect of which the advance is made and on his interest in any other land.

s. 14 (1)-Provides for a Caveat in Form $\mathbf{C}$ to be filed. s. 26-Discharge of caveat to be in Form $D$.

s. 2-Approves the agreement set out as a schedule. Agreement provides for transfer of Public Lands to the Province, School Lands, Water, Fisheries, Indian Reserves, Soldier Settlement Lands, National Parks, Seed Grain Liens, General Reservation to Canada.

(NOTE: This agreement came into force on the 1st day of October, 1930. (1931 S.A. c. 5.) )

s. 12 ; s. 15 (2)-Conveyance or transfer of a lot, plot, crypt or compartment need not be registered under the Land Titles Act.

s. 286 (1)-The title to every public highway, road, street, lane, alley, boulevard, park, square, bridge or other public place in every city, except as far as excluded by a special Act or agreement, is vested in the City.

s. 289 (1)-Council may grant . . . privilege of erecting a structure overhanging the highway or public place or of excavating under the highway etc.

s. 318-Power of disposal of land by council.

s. 319-Council of a City subject to Tax Recovery Act in disposing of property finally acquired by tax recovery proceedings.

s. 340 (9), (10), (10a);-Value of any assistance given to any resident indigent or not for food ... . \&c hospitalization and burial is a charge on the lands of any person for whose benefit it was given or paid .... and council may file a caveat in proper land titles office etc.

s. 483- . . . taxes not a charge on real estate or the building ...

s. 3-The owner of the surface of land is and shall be deemed at all times to have been the owner of and entitled to clay and marl on the surface of that land, and all clay and marl obtained by stripping off the overburden, excavating from the surface, or otherwise recovered by surface operations.

s. 4 (1)-The clay and marl referred to in section 3 shall be deemed not to be a mine, mineral or valuable stone but shall be deemed to be and to have been part of the surface of land and to belong to the owner thereof.

(2)-Notwithstanding any patent, title, grant, deed, notification, conveyance, lease, license, argeement, disposition or other document heretofore or hereafter issued or made that contains or reserves mines, minerals or valuable stone, the owner of the mines, minerals or valuable stone in any land is not entitled to the clay and marl referred to in section 3 as against the owner of the surface of the land.

s. 2-A Barrister and Solicitor of the Province is a Commissioner and always has been a commissioner...

s. 3 \& s. 4-Lieutenant Governor in Council may empower ... persons to be commissioners within and without the Province.

s. 5-Person holding a commission in Canadian Forces ex officio a commissioner within or without the Province.

s. 6-Member of Legislative Assembly of Alberta ex officio a commissioner within or without the Province. 
Communal Property

Act.

1955 R.S.A. c. 52.

Companies Act. 1955 R.S.A. c. 53

s. 11 (1)-No person shall sell ... to a colony ...

s. 11 (2)-Any transfer, agreement or lease contravening subsection (1) is absolutely null and void ...

s. 10 (2)-Every corporation is capable of acquiring and holding any real or personal property in joint tenancy ... s. 19 (1) (a)-Power of a company to hold real debenture,

(b) on uncalled or unpaid share capital (c) as a floating charge on its undertaking on property or (d) as a mortgage or charge on goodwill or any patent ... trade mark ... or any copyright shall be registered with Registrar of Companies ... within 60 days of its creation.

s. 99 (4) - No mortgage of land duly registered under the Land Titles Act becomes void under subsection (1) by reason of the fact that the mortgage is not registered under the Companies Act.

s. 102 (1)-Every company shall keep at its registered office a register of mortgages ... .

s. 162 (2)-No corporation, including a foreign company, that is not registered under the provisions of this Part or of Part III or otherwise authorized to do so by Act of the Province is, while unregistered, capable of acquiring or holding lands or any interest therein in the Province, or of registering any title thereto under The Land Titles Act.

(See also Section 30 of The Land Titles Act. 1955 RSAc. 170.) s. 208-Powers of Liquidator in winding up by the court. s. 228-Powers of Liquidator in voluntary winding up.

Condominium Property Act provides for Certificate of Titles to parts of a building, Act.

1966 S.A. c. 19. the rights and liabilities of the owners and the management of the building.

County Act. 1955 R.S.A. c. 64.

Devolution of Real Property Act. 1955 R.S.A. c. 83. s. 7 (1)-Upon publicaton of the order establishing a county, the Minister of Education in the case of school divisions and the Minister of Municipal Affairs in the case of municipalities, shall proceed to divide and apportion the assets and liabilities of any school division or municipality that is partly included in the county.

s. 10 (d)-Upon the effective date of the establishment of the county, all properties and all other assets and liabilities that belong to each municipality and school division that is wholly included within the County shall be vested in the county. s. 10 (e)-All properties, ... that have been divided under section 7 ... shall be vested in the county.

s. 10 (f)-all remedies that were available for the collection of any taxes due a municipality or school district shall be available to the county ...

s. 25-The provisions of the Municipal District Act in so far as they are not inconsistent with this Act, apply to every county.

s. 2 (c)-"personal representative" means the executor . . . or administrator for the time being of a deceased person.

s. 3 (1)-Real property ... of deceased person ... devolves upon and becomes vested in his personal representative. s. 4-... personal representative holds as trustee for persons by law beneficially entitled thereto and they have right to require a transfer.

s. 7 (1) \& (2) - . . personal representative may convey subject to a charge or without any such charge.

s. 10-Personal representative may sell the real property ... and it is not necessary that beneficiaries concur. . . except where sale is made for the purpose of distribution only.

s. 14 (1)-The personal representative may-(a) lease the real property or a part thereof for a term of not more than one year (b) for a longer term with approval of court (c) raise money by way of mortgage ...

s. 15 (2)-So long as real property that has been conveyed by the personal representative to a person beneficially entitled thereto remains vested in that person; or in a person 
Domestic Relations

Act.

1955 R.S.A. c. 89.

Dower Act. 1955 R.S.A. c. 90.

\section{Drainage Districts \\ Act. \\ 1955 R.S.A. c. 91.}

Evidence Act. 1955 R.S.A. c. 102. claiming under him not being a purchaser in good faith and for value, it continues to be liable for debts of deceased owner...

s. 20-When an application for alimony is made, the court may ... grant an injunction ... to prevent any ... disposition by the defendant of his real or personal property.

s. 21-An order of judgment for alimony ... may be registered in any land titles office, and the registration (a) binds the estate .... that the defendant has in the lands in the land registration district where the registration is made and (b) operates ... in the same manner as a ... charge ... of a life annuity on his lands.

s. 22-Settlement of property where husband has obtained a judgment.

s. 23-Payment to wife after divorce or nullity.

s. 24-Disposition of property comprised in an ante nuptial or post-nuptial settlement.

All sections relevant to disposition of homestead of wife or husband, and too lengthy to summarize.

s. 2 (c)- "Homestead" means a parcel of land-

(i) on which dwelling house occupied by the owner of the parcel is situated, and

(ii) that consists of -

(A) not more than four adjoining lots ...

(B) not more than one quarter section of land ...

s. 49-The debentures . . . are a charge upon ... (c) all rates levied ... but have no priority over any charges, liens, mortgages or encumbrances upon such land and created or coming into existence before the issue of the debentures.

s. 175 (1)-Provides for Drainage rate enforcement return. s. 178-Confirmation of return by District Court Judge.

s. 182 (2) \& (5)-The adjudication when registered in Land Titles Office-

(a) vests the lands in the Board ... and the Board obtains an estate in fee simple to the lands.

s. 182 (3)-The estate in fee simple is free from all other estates and from all liens, agreements for sale, mortgages and encumbrances of every nature and kind, other than

(a) ... Crown in Right of Canada.

(b) The charge imposed by any debentures issued under the provisions of this Act.

(c) Taxes and rates.

(d) Easements under Sec. 70 and 71 of Land Titles Act.

(e) Condition or covenant running with or annexed to land registered under Section 52 of the Land Titles Act.

(NOTE: See Sec. 64 (1) (b) Land Titles Act-Drainage and Irrigation rates implied condition without need of being mentioned in a title.) (Se also Sec. 23. L.T.A.)

s. 54 (1)-Copy of a registered document under hand and seal of Office of Registrar or Deputy Registrar under Land Titles Act prima facie proof ...

s. 54 (2)-An abstract of title or a general certificate under seal furnished by a Registrar in the Province is prima facie proof of the contents thereof.

s. 58-Where an attestation to an instrument is not requisite to the validity of the instrument, it is not necessary that the instrument be proved by the attesting witness.

(NOTE: See Section 158 Land Titles Act for instruments that do not need attestation.)

s. 61- . . . recitals, statements of facts and matters and descriptions of parties contained in deeds, instruments, Acts or statutory declarations that are 20 years old at date of the contract for sale of land shall be taken to be sufficient proof of the truth of the recitals ... 
Execution Creditors

Act.

1955 R.S.A. c. 103.

Exemptions Act. 1955 R.S.A. c. 104.

Expropriation Procedure Act. 1961 S.A. c. 30.

Family Relief Act. 1955 R.S.A. c. 109.

Gas Utilities Act. 1960 S.A. c. 37.

Hospitals Act. 1961 S.A. c. 36

Improvement Districts Act.

1965 S.A. c. 39. s. 2 (b)-“Execution" means a writ of fieri facias, and every subsequent writ for giving effect to a writ fieri facias. (Rule of Court. No. 391-"Every writ of fieri facias shall be issued against both the goods and lands of the debtor.")

s. 2-The following real ... property of an execution debtor is exempt from seizure under any writ of execution;

(j)-The homestead of an execution debtor actually occupied by him provided it is not more than 160 acres.

(k)-The house actually occupied by the execution debtor and buildings used in connection therewith and the lot or lots on which the house and buildings are situated according to the registered plan thereof, if the value of the house, building and the lot or lots does not exceed $\$ 8,000.00$. s. 8-Section 2 does not apply-

(a) where the execution debtor has absconded or is about to abscond from the Province, leaving no wife or husband or infant children within the province, or

(b) to an execution issued upon a judgment or order

(i) for payment of alimony or for the payment of maintenance by a husband to his wife or his former wife as the case may be, or

(ii) for the payment of maintenance for any child of the execution debtor.

s. 3-This Act applies to any expropriation authorized by the law of the Province and prevails over any contrary provisions therein ..

s. 5 (1)-Unless the authorizing Act expressly authorizes the expropriation of mines and minerals, the expropriation authority is not entitled to any mines and minerals.

s. 7 to s. 21-Expropriation by Crown (Province of Alberta).

s. 22 to s. 30-Expropriation by Municipalities.

s. 31 to s. 39-Expropriation by Companies.

s. 40 to s. 41-Expropriation by other bodies

s. 5-The benefits to such a spouse is entitled under the provisions of The Dower Act shall be taken into account when determining the provision that ought to be made for the spouse out of the estate.

s. 6 (1)-The judge in any order making provisions for maintenance and support of a dependent may impose such conditions as he deems fit.

s. 6 (4)-Where a transfer or assignment of property is ordered, the judge-

(a) may give all necessary directions for the execution of the transfer or assignment by the executor or administrator or such other person as the judge may direct, or

(b) may grant a vesting order.

s. 24 (1)-No owner of a gas utility shall ..

(g) without the approval of the Board

(i) sell, lease, mortgage, or otherwise dispose of or encumber its property, franchises, privileges or rights or any part thereof, or

(ii) merge or consolidate its property, franchises, privileges or rights or any part thereof with that of any other owner of a gas utility or public utility within the meaning of The Public Utilities Board Act and every sale, lease, mortgage, disposition, encumbrance, merger, or consolidation made in contravention of this clause is void and of no effect. .

s. 10 (1)-Where a district board requires land as a site for hospital buildings, it may expropriate the land required.

s. 20 (2)-All taxes due in respect of any property or business together with costs and interest, are in lien on the property or stock in trade of the business, if not exempt from taxation by the Province, in prority to every claim, lien or encumbrance, except a lien, claim or encumbrance of the Crown. 
Infants Act.

1955 R.S.A. c. 158.

Intestate Succession

Act.

1955 R.S.A. c. 161.

Irrigation Districts

Act.

1955 R.S.A. c. 162.

Judicature Act.

1955 R.S.A. c. 164.

Juvenile Court Act. 1955 R.S.A. c. 166.
Act deals mostly with procedure concerning dealings with rights of infants in real property and is too long to summarize here. The Infant Act should be read in conjunction with Sections 127, 155, 199 and Form 38 of The Land Titles Act.

All sections relevant to descent of real property in intestacy and too long to be summarized here.

s. 2 (f)-“first mortgage" means any mortgage or encumbrance registered . . . before the formation of the district. s. 13 (b) (4)-After the filing of the copy of the resolution no instrument given by the registered owner or any other person owning any estate or interest in the land and purporting to transfer, sell, agree to sell, lease, sublease, mortgage, encumber or otherwise deal with a part only of the irrigable unit is valid or effective until the instrument is consented to by the board and a memorandum of the board's consent is endorsed on or annexed to the instrument.

s. 53 (c)-The debentures .... are a charge or lien upon all rates levied . . . but have no priority over any charges, liens, mortgages or encumbrances upon such land and created or coming into existence before the issue of the debentures.

s. 62 (1) -the irrigation rates, when calculated form a special lien upon each parcel of land within the district and containing any portion of the land to be irrigated.

s. 62 (2)-the rates ... are a special lien upon the land and have priority over all claims, liens, privileges, or encumbrances thereon except claims of the Crown, first mortgages, within the meaning of this Act and such claims, liens, charges, or encumbrances as may hereafter be expressly expected from the operation of this section.

s. 167 (1)-Provides for irrigation rate enforcement return.

s. 170-Confirmation of return by district Court Judge.

s. 174 (2) \& (5)-The adjudication when registered in Land Titles Office-

(a) vests the land in the board .... and the board obtains an estate in fee simple to the lands ...

s. 174 (3)-The estate in fee simple is free from all other estates and from all liens, agreements for sale, mortgages and encumbrances of every nature and kind, other than

(a) Crown in right of Canada,

(b) the charge imposed by any debentures issued under the provisions of this Act or first mortgages within the meaning of this Act,

(c) taxes and rates ...

(d) easements under 70 and 71 of The Land Titles Act,

(e) condition or covenant running with or annexed to land registered under Sec. 52 of The Land Titles Act. (SPECIAL NOTE: See Sec. 64 (1) (b) Land Titles ActDrainage and Irrigation rates implied condition without need of being mentioned in a title.)

s. 22 (1)-Where the court has authority to order the execution of a deed, conveyance, transfer or assignment of any property, real or personal the Court may by order vest such real or personal estate in such person or persons and in such manner and for such estates as would be done by any such deed, conveyance, transfer or assignment if executed.

s. 34 (17)-In an action brought upon a mortgage of land whether legal or equitable or upon an agreement for sale of land, the right of the mortgagee or such vendor thereunder is restricted to the land ...

s. 34 (21)-Any waiver or release of Sec. 34 (17 \& 18) is against public policy and void.

s. 35-s. 34 (17) to (21) does not apply if mortgagor or purchaser is a corporation.

s. 31 (2)-The municipality has a charge upon the land situate within the Province and owned by the parent or parents or either of them for the expenses, maintenance or support order to be paid by the municipality under Section 29. 
Land Surveyors Act. 1965 S.A. c. 44.

Land Titles Act. 1955 R.S.A. c. 170.

Land Titles Act. Clarification Act. 1956 S.A. c. 26.

Landlord and Tenant Act.

1964 S.A. c. 43.

Landlord's Right in Bankruptcy Act 1955 R.S.A. c. 171.

Department of Lands and Forests Act. 1955 R.S.A. c. 172. s. 35-The Registrar shall

(a) not later than the first day of March in each year

(i) prepare an annual membership list showing the names and addresses of all active members registered as of the preceding first day of February, and

(ii) send a copy of the list to each member and to the Director of Surveys, and each Registrar of Land Titles,

and

(b) keep the register at his office for public inspection without charge.

Citations of former Land Titles Acts that were in force in the Province of Alberta-

Territories Real Property Act - 1886 S.C. c. 26.

$\begin{array}{ll}\text { Land Titles Act } & -1886 \text { R.S.C. c. } 51 . \\ \text { Land Titles Act (Dominion) } & -1894 \text { S.C.c. } 28 . \\ \text { Land Titles Act (Alberta) } & -1906 \text { R.S.C. c. } 110 . \\ \text { Land Titles Act } & -122 \text { R.S.A. c. } 24 . \\ \text { Land Titles Act } & -1942 \text { R.S.A. c. } 133.205 .\end{array}$

s. 2-It is hereby declared that the term "lease" as used in The Land Titles Act and any Act for which The Land Titles Act was substituted includes, and shall be deemed to have included, an agreement whereby an owner of any estate or interest in any minerals within, upon or under any land for which a certificate of title has been granted under The Land Titles Act or any Act for which The Land Titles Act was substituted, demises or grants or purports to demise or grant to another person a right to take or remove any such minerals for a term certain or for a term certain coupled with a right thereafter to remove any such minerals so long as the same are being produced from the land within upon or under which such minerals are situate.

s. 2-Act does not apply to minerals held separately from the surface of land or any dealings in minerals.

(NOTE: other sections deal with termination of lease and obtaining possession.)

s. 3-As soon as the receiving order or assignment is made,

(a) the landlord of the lessee is not thereafter entittled to distrain ...

(b) the trustee .... shall pay to the landlord in priority to all other debts, -

(i) an amount not exceeding in value the distrainable assets and not exceeding 3 months rent ... (ii) the costs of distress.

s. 4-the lessee is a debtor to the landlord-

(a) for all surplus rent in excess of the 3 months rent accrued ...

(b) for any acceleration rent ... not exceeding ... 3 months rent.

s. 5-Except as aforesaid the landlord has no right to claim as a debt any money due to him ... for any portion of the unexpired term of the lease.

s. 13-(1) where a disposition of an interest in Crown land other than mines and minerals is made,... the assignment may be registered with the Minister.

(2) -The Minister shall cause to be kept . . . books for the registering of assignments.

(3) The Minister may refuse to register an assignment unless-

(a) the assignment is unconditional,

(b) all the persons to whom the disposition was made are the assignors.

(c) and (d) assignment is duly executed and in proper form. 
Legal Profession Act 1966.

1966 S.A. c. 46.

Limitation of Actions Act.

1955 R.S.A. c. 177.

Line Fence Act. 1955 R.S.A. C. 178 s. 17-The date of registration endorsed upon the original copy of the assignment retained by the Department is conclusive proof of the date of registration under Section 13 and an assignment registered under Section 13 is valid against and takes priority over any unregistered assignment.

s. 88 (1)-No person shall, unless he is an active member of the Society,

(a) practise or act as a barrister or as a solicitor, or

(b) act as a barrister or as a solicitor in any court of civil or criminal jurisdiction, or

(c) commence, carry on or defend any action or proceeding before a court or judge on behalf of any other person, or

(d) settle or negotiate in any way for the settlement of any claim for loss or damage founded in tort.

(2) Subsection (1) does not apply to

(a) any public officer who draws or prepares any document in the course of his duties,

(b) a notary public exercising the powers conferred upon him by law,

(c) any person who acts on his own behalf in an action, matter or proceeding to which he is a party,

(d) any person who draws, prepares, revises or settles for his own use any will, any conveyance or other instrument pertaining to real or personal property, or any other instrument or document that is or intended to be enforceable by law or have a legal effect,

(e) any insurance adjuster acting under The Alberta Insurance Act,

(f) Any person who appears as an agent for another person before a justice of the peace or magistrate when authorized to do so under an Act of the Parliament of Canada or the Province, or

(g) an articled student-at-law in the course of acting as counsel in any of the cases enumerated in section 87 or in doing anything in the course of his service under articles, if it is done under the direction or supervision of an active member.

(3) The exemption provided by clause (c) of subsection (2) does not apply to a person to whom debt has been assigned for collection purposes only.

s. 2 (b) - "assurance" means a transfer, deed or instrument other than a will, by which land may be conveyed or transferred.

(e) "land" includes

(i) corporeal hereditaments, and

(ii) a freehold or leasehold estate or an interest therein;

(f) "mortgage" includes a charge and "mortgagor" and "mortgagee" have means similarly extended.

(i) "rent charge" includes annuities and periodical sums of money charged upon or payable out of land.

s, 49-No right to the access and use of light or any other easement, right in gross or profit a prendre shall be acquired by a person by prescription, and it shall be deemed that no such right has ever been so acquired.

(NOTE: For Limitation periods on all sections including actions on real property see Volume 2, Alberta Law Review, Page 96 at 106 and 107).

s. 3 (1)-Whenever two owners or occupiers of adjoining parcels of land desire to erect a line or boundary fence ... they shall bear the expense of the erection, maintenance and repair of the fence in equal shares.

(2)-Whenever the owner or occupier of a parcel of land erects a fence-the owner-of the adjoining parcel ... . shall as soon as he receives any benefit ... shall pay to the first mentioned owner .... a just proportion .... and thereafter the expense of maintaining and repairing ... shall be borne by the owners in equal shares. 
Local Authorities Board Act.

1961 S.A. c. 46

Local Tax Arrears Consolidation Act. 1955 R.S.A. c. 185.

Maintenance Order

Act.

1955 R.S.A. c. 188. s. 27 (1)-The Board has all the necessary jurisdiction and power-

(f) to order compromises of tax arrears as provided by this Act,

(g) to deal with plans of subdivision as provided in this Act.

s. 58 (1) -In the case of an order of the Board for payment of any money, costs, expenses or penalty, a certified copy of the order signed by the secretary may be registered in any Land Titles Office in the Province.

(2) - . . the order constitutes a lien and charge upon the land ...

s. 117-If the amount of the arrears . . . is not paid . .. the Board may order that the title to the land, excluding the Mines and Minerals . . . be transferred to the local authority or Minister ...

s. 129 (1)-Upon the application of the registered owner . . . of any land included in a registered plan of subdivision .... the Board may order the cancellation, in whole or in part, or the amendment or alternation, of the registered plan.

s. 130-The Board may by the order direct that any land in the subdivision, or any right or any interest in any land therein, be vested in the applicant and the Board may make such order as to the vesting or revesting of any land included in the plan or survey as it thinks fit

s. 133 (1)-Whenever ... any roads, streets or lanes would vest in a mortgator, then the Board may direct that such roads . . . be included in any mortgage ...

s. 13-Upon the receipt by the Registrar of a notice from a treasurer that any taxes in respect of a parcel have been consolidated pursuant to this Act-

(a) The Registrar shall make an entry to that effect on the title to the parcel.

(b) thereafter and until the entry is cancelled or superseded the Registrar shall not register or give effect to an assurance of any kind effecting title to the parcel and that depends for its validity upon The Tax Recovery Act...

s. 6-An order made under this Act may direct the sheriff to levy upon the lands, goods and chattels of the persons against whom the order is directed for the money recoverable under the order.

Married Women's Act. 1955 R.S.A. c. 193.

s. 4-A married woman is capable-

(a) of acquiring, holding, disposing of or otherwise dealing with every kind of real and personal property ... as if she were an unmarried woman.

s. 8-For the avoidance of doubt it is hereby declared that nothing in this Act--

(c) prevents a husband and wife from

(i) acquiring, holding and disposing of any property jointly or as tenants in common in like manner as if they were not married.

Mechanics' Lien Act. 1960 S.A. c. 64. s. 32-Liens may be registered within 35 days generally, 120 days where oil or gas wells or pipe lines are concerned, 60 days for wages in or about a mine.

s. 33-Where a lien is not registered within the time limited by section 32 , the lien ceases to exist.

s. 34 - Lien ceases 30 days from date notice to take proceedings (Form 4) is-

(a) served on lienholder ...

(b) deposited in the mail by registered mail ... s. 35-Lien ceases to exist 6 years from registration unless renewal filed...

s. 36 (1)-Notwithstanding s. 34 and s. 35 lien does not cease if lis pendens (Form 5) is filed with Registrar ... 
Mentally Incapacitated Persons Act. 1955 R.S.A. c. 201.

Metis Betterment Act. 1955 R.S.A. c. 202.

Mineral Declaratory

Act.

1961 S.A. c. 48.

Mineral Interests Compensation Act. 1958 S.A. c. 43.

Mineral Taxation Act. 1955 R.S.A. c. 203. s. 3 (1)-The Court, subject to the provisions of The Public Trustee Act may make orders for committing the custody of persons of unsound mind and the custody and management of their estates to a committee consisting of one or more persons. s. 12 (2)-To facilitate administration, the Court in its discretion may by order-

(a) Vest any of the property of a person of unsound mind in the Committee.

(b) Appoint some person to transfer the property to the committee or as the court directs.

s. 16-The court may, by order, on such terms and conditions as it deems just, authorize and direct a committee to

(a) sell property and accept mortgages for purchase money,

(b) exchange or partition property ...

(d) grant leases of property

(e) surrender a lease ...

(f) with or without consideration, surrender, transfer or otherwise dispose of onerous property.

s. 21 (1)-Where property within the Province stands in the name of or is vested in a person residing out of the Province, the Court upon proof-

(a) that the person has been declared or found of unsound mind,

(b) that his property has been committed to a person appointed to manage it,

may order that the property within the Province or a part thereof be vested in the person so appointed.

s. 18 (1)-No person shall take or become entitled to the benefit of a security, charge or lien on the property of a person ... or wife, husband or minor child of such member ... and every such security, charge or lien is void ...

s. 3-Each substance named in schedule that naturally occurs within, upon or under land is hereby declared to be and at all time to have been a mineral (Schedule names-Anhydrite, Barite, Bauxite, Bentonite, Diatomite, Dolomite, Epsomite, Granite, Gypsum, Limestone, Marble, Mica, Mirabilite, Potash, Quartz Rock, Rock Phosphate, Sandstone, Serpentine, Shale Slate, Talc, Thenardite, Trona, Volcanic Ash.)

s. 4-Where any of these substances have been removed befor the commencement of this Act ... . by someone acting in good faith .... no right of action lies.

s. 5-a person who owns or has an interest in the surface can disturb the substance...

s. 6-Where Crown or municipality owns surface ... has right to excavate ... . without permission or compensation.

s. 3-A person deprived of minerals solely by or as a result of an error of a registrar made since 1st September, 1906 could bring an action... against Registrar as a nominal defendant until 31st March, 1961.

s. 20-Where a tax arrears notification has been filed by the Registrar... the Registrar shall not cancel the Certificate of Title to the mineral or minerals affected until it is discharged....

s. 24 (1)-The taxes and penalties payable by a person pursuant to this Act:

(a) shall be deemed to be a debt due to the Crown and s. 24 (2) \& (3) - . . shall constitute a charge ... . which has priority over other charges, mortgages, liens or encumbrances except a lien for wages under the Mechanics' Lien Act.

s. 25 (5)-The registrar shall file the notification and endorse a memorandum thereof upon the Certificate of Title.

s. $25(10) \&(11)$ - If at the expiration of 1 year after the date of notice ... the taxes due . . . are not paid ... the Deputy Minister ... may deliver or mail to the Registrar a notice in Form C . . . and ... the Registrar shall cancel the Certificate of Title of the owner and the title ... vests in the Crown in the right of the Province. 
Mineral Titles

Clarification Act.

1956 S.A. c. 32.

Mineral Titles

Redemption Act. 1958 S.A. c. 44.

Mines and Minerals Act.

1962 S.A. c. 49.

Municipal Districts

Act.

1955 R.S.A. c. 215.
Act to resolve doubt as to ownership of certain minerals under roads ... or lands reserved for public purposes. (Too lengthy and technical to summarize.)

s. 4 (1)-A person whose minerals have vested in Her Majesty under the Mineral Taxation Act 1945 or the Mineral Taxation Act 1947 or a person on his behalf may, on or before the 31st day of March 1961 apply to the Superintendent of Mineral Tax to recover title to the minerals.

(NOTE: This Act deals with Crown Minerals.)

s. 2 (1) (m)-"Mineral" means all naturally occurring minerals but does not include-

(a) sand and gravel that belong to the owner of the surface of the land under The Sand and Gravel Act.

(b) clay and marle that belong to the owner of the surface of land under The Clay and Marl Act; or

(c) Peat on the surface of land and peat obtained by stripping off the overburden, excavating from the surface or otherwise recovered by surface operations.

s. 19-No grant from the Crown ... has operated or will operate as a conveyance of gold and silver ...

s. 21 (1) \& (3)-Where any person is entitled to receive title in fee simple to any minerals ... . for which certificate of title has already been issued ... a transfer shall be issued by the Minister or Deputy Minister ... and upon receipt of the transfer the Registrar (Land Titles) shall issue a new certificate of title.

s. 22 (1)-When any person is entitled to receive a title . . . to any minerals ... where no certificate is registered ... a notification in Form $A$ shall be issued.

s. 23 \& 24-Minerals under roads, roadways, and trails. (See Act-summary could be misleading).

s. 28-If an agreement is found to cover any mineral included in any disposition of prior date, the agreement is void in so far as it interferes with the previous disposition.

s. 175 to 181-Provides for registration of transfers and documents with Minister.

s. 20 (o)-"Land" means lands, tenements and hereditaments and any estate or interest therein and includes growing timber but does not include minerals.

s. 23 (2)-All questions arising over the division or apportionment of the property (as between dissolved and new districts) shall be decided finally and without appeal by the Minister. (3)-This section is subject to Tax Recovery Act, (1955 R.S.A. c. 334 Sec. 37 .)

s. 234 (1)-The title to all public roads, highways, streets, and lanes in a municipal district is vested in the Crown in the right of the Province.

(2)-Each such public road, highway, street and lane, except a main or secondary highway established as such under the Public Highways Act is subject to the direction, control and management of the council of the municipal district in which it is situated subject however to the provisions of The Water, Gas, Electric and Telephone Companies Act and the Pipe Line Act, 1958.

s. 247 (1) -Subject to the approval of the Minister of Highways, the council may pass a by-law to close any public street, lane, road or highway or any portion thereof permanently or temporarily.

s. 249 \& 249-Powers of Municipality to acquire land (too lengthy to summarize.)

s. 255-(1) A council may expropriate land that the council is authorized to acquire or that is necessary for the use, construction, maintenance or repair of any municipal works authorized by this Act or that is necessary for obtaining better access thereto. 
s. 269-(1) A council may pass a by-law

(a) to sell, lease or otherwise dispose of, or

(b) to devote to some other municipal purpose, in whole or in part any property acquired by the municipal district by gift or otherwise for a specific purpose, when the property in the opinion of the council, is no longer needed for the specific purpose.

s. 269 (2) - A council with the approval of the Highways Department may sell or lease any land formerly part of a highway, road, street or lane but no longer required ... (2) (a)-Council may sell ... any property acquired from the Government of Canada for the purpose of establishing an industry or other commercial enterprise ...

(3)-A transfer ... shall be executed ... by affixing the Seal of the municipal district attested by the reeve and the Secretary-Treasurer.

(4)-Tax Recovery Act applies ...

S. 294 (11) \& (12)-The value of any assistance . . . for food, fuel ... hospitalization .... is a charge on the lands of a person for whose benefit it was given and the municipal district may lodge a caveat . . . in a land titles office.

s. 305 (1) \& (3)-When the municipal district advances a commodity ... a lien in Form 25 in Schedule $A$ shall be taken for a change upon the land and upon his interest in any other land.

s. 354 (2)-The taxes, costs and interest referred to in subsection (1) are a special lien on

(a) the land

(a1) the business

(a2) assessed property under the Electric Power and Pipe Line Assessment Act,

(b) personal property,

(c) mineral or timber that is not exempt from taxation by the Province

in priority to a claim, privilege, lien or encumbrance of any person except the Crown and the lien and its priority are not lost or impaired by any neglect, omission or error.

s. 370-A tenant or purchaser may deduct from his rent or moneys payable under his contract of purchase any tax paid by him ...

s. 427-Gravelpit owned by a municipality does not change ownership by reason of change in boundary ...

s. 430-No person shall, by reason of the adverse or unauthorized possession, occupation, enjoyment or use of any land owned by a municipal district obtain any estate or interest therein, and it shall be deemed that no such right has heretofore been so acquired.

Municipal Districts Act. 1959 S.A. c. 55

s. 22-(1) For the purpose of quieting certain titles to land acquired in municipal districts by or through tax recovery and sale proceedings under statutory authority in the years 1930 to 1947, it is hereby declared that clause (b) of section 2 of chapter 48 of the Statutes of Alberta, 1930 amending clause (1) of section 2 of chapter 41 of the Statutes of Alberta, 1926, being an Act entitled the Municipal District Act, was effective to and did remove from the definition of "mineral" for the purposes of the said Act and chapter 151 of the Revised Statutes of Alberta, 1942, all minerals other than coal for the period from the twenty-first day of March, 1930, to the thirtyfirst day of March 1947.

(2) This section shall not be construed so as to divest a bona fide purchaser for value of an interest in minerals acquired by registration under The Land Titles Act.

(See also Tax Recovery Act 1955 R.S.A. c. 234, s. 21)

Municipal Improvements Assistance (Alberta) Act. 1955 R.S.A. c. 217. s. 12-(1) As security for repayment by a municipality . - . the Lieutenant Governor in Council may require a first mortgage in Form B ... on the works to be constructed ... 
Municipal and School Administration Act. 1962 S.A. c. 54.

Names of Homes Act. 1955 R.S.A. c. 219.

National Housing Loans Act (Alberta). 1955 R.S.A. c. 220.

New Towns Act. 1956 S.A. c. 39.

Notaries Public Act. 1955 R.S.A. c. 222.

Noxious Weeds Act. 1955 R.S.A. c. 223.

Oil and Gas Conservation Act. 1957 S.A. c. 63. s. 2-(1) Subject to the approval of the electors, the the municipal and school administration in a city or town may be merged in the manner hereinafter provided.

(2)-This Act does not apply with respect to

(a) A separate School District

(b) A consolidated School District

(c) A city or town district that is included within a county or a school division.

s. 7-(1) Upon the effective date of the order

(a) all the property and all other assets and liabilities of the School District become vested in the city or town.

s. 2 (b)-“Registrar" means Deputy Minister of Agriculture. s. 3, 4, 5, 6-A person owning a home ... and desiring to register a name... may make a declaration ... in Form A and in Form B .... and file it with the Registrar ....

s. 11-... every name registered ... . attaches to the land ... and passes with the transfer ... demise ... or to his executor or administrator.

s. 2-Where a loan is made under the provisions of the $\mathrm{Na}$ tional Housing Act (Canada), or the National Housing Act 1954 (Canada) and secured by a mortgage on lands in the Province, the following statutory provisions have no application to the mortgage or to the rights and remedies of the mortgagee:

(a) clauses (h) to (j) of Section 32 and subsections (17) to (20) of Section 34 of the Judicature Act

(b) Section 119 of the Land Titles Act.

S. 26-For the purposes of the Acts listed in the Schedule in the New Towns Act, and any other Act of the Legislature... a new town shall be deemed to be a town ...

s. 4-(1) A notary public may, during pleasure

(a) administer oaths attested by his signature and seal

(b) draw, pass, keep and issue deeds ...

(2) Where oath affidavit, affirmation or declaration within the Province for use within the Province it is not necessary to their validity that he affix his seal thereto.

s. 51 (1)-If a sum or part thereof due and payable for expenditure as mentioned in section 50 remains unpaid at the fifteenth day of December next after the making of such expenditure the amount of such unpaid expenditure shall be added to and forms part of the ordinary taxes levied against the parcel of land by the city, town, village, municipal district, county or improvement district in which the parcel is situated.

s. 2 (b2) - "crude oil" means a mixture mainly of pentanes and heavier hydrocarbons that may be contaminated with sulphur compounds, that is recovered or is recoverable at a well from an underground reservoir and that is liqued at the conditions under which its volume is measured or estimated, and includes all other hydrocarbon mixtures so recovered or recoverable except raw gas or condensate;

s. 2 (d)- "field" means

(i) the general surface area in areas underlaid or appearing to be underlaid by one or more pools, or

(ii) the subsurface regions vertically beneath such surface area or areas.

s. 2 (e)- "gas" means raw gas or marketable gas or any constituent of raw gas, condensate or crude oil that is recovered in processing and that is gaseous at the conditions under which its volume is measured or estimated.

s. 2 (m)- "owner" when that term is used in connection with a well, includes the person who is entitled to produce and dispose of any oil or gas from the well, or property or who 
would be entitled in the absence of any contract, statute, regulation or order governing the disposition of production. s. 50 (1)-In this part "oil and gas property" means the right, title or interest of any person to or in any oil or gas that is in the earth in the Province and includes

(a) every kind of right to search for or obtain production of any oil or gas whether the right is incidental to the ownership of land or is created by a lease, permit, contract or in any other way,

(b) every right, title, interest or benefit acquired or withheld upon the making of any sale, lease, sublease, assignment, licence or other arrangement relating to the disposition of any right, title or interest to or in any oil or gas,

(c) any interest of the Crown under any sale, grant, lease, licence, reservation or other agreement or permit made or issued by the Crown in respect of any oil or gas, and

(d) oil and gas, the property of the Crown, not subject to a sale, grant, lease, licence, reservation or other agreement or permit.

s. 64 (1)-After the date of mailing the notice referred to in section 60 , the Board has a lien or charge, for the amount remaining unpaid of the taxes and penalties added thereto, upon the oil and gas property in respect of which the taxes and penalties are payable under the provisions of this Part.

Partnership Act. 1955 R.S.A. c. 230 .

Proceedings against the Crown Act. 1959 S.A. c. 63.

Pipe Line Act, 1958. 1958 S.A. c. 58. s. 4-In determining whether a partnership does or does not exist, regard shall be had to the following rules:

(a) Joint tenancy, tenancy in common, joint property, common property or part ownership does not of itself create a partnership is to anything so held or owned, whether the tenants or owners do or do not share profits made by the use thereof;

s. 22 (3)-Where co-owners of an estate or interest in land that is not partnership property are partners as to the profits made by the use of that estate or interest in land out of such profits, and to be dealt with in like manner, the estate or interest so purchased belongs to such co-owners, in the absence of an agreement to the contrary, not as partners but as were held by them at the date of purchase in the first mentioned estate or interest in land.

s. 24-Where land or an interest in land becomes partnership property, it shall, unless the contrary intention appears, be treated as between partners, including the representatives of a deceased partner, as personal or moveable property and not as real property.

s. 18-In proceedings against the Crown in which the recovery of real or personal property is claimed the Court shall not make an order for its recovery or delivery but in lieu thereof may make an order declaring that the claimant is entitled as against the crown to the property claimed or to the possession thereof.

s. 2 (1) (m)-"Minister" means the Minister of Mines and Minerals.

s. 2 (2)-The decision of the Minister is final as to whether or not a pipeline is a gas line, oil line, mineral line, secondary line, or flow line or a distribution line or private line within the meanng of Part $V$ and there is no appeal therefrom.

s. 34 (1)-The Minister may, upon such terms and conditions as he deems proper, direct a licensee to alter or relocate any part of his pipe line if in the Minister's opinion the alternation or relocation would be in the public interest.

s. 40 (1)-Where an operator requires an interest in land for the purposes of his pipe line he may expropriate the interest required by an order under The Expropriation Procedure Act. 
Planning Act. 1963 S.A. c. 43.
(2)-Where an order or orders are made with respect to a processing plant the area of land in which an interest is vested for the site of the processing plant shall not exceed five acres in the aggregate.

(3)-An order vests in the operator, unless otherwise provided in the order, an exclusive interest in the land described in the order for the purposes named therein, with such annexed rights in or over the other land as may be specified in the order, but the order does not give an operator

(a) any right or entitlement to a certificate of title under The Land Titles Act for the interest in land acquired by the operator by the order, or

(b) the right to carry away sand and gravel from the land in respect of which the order was made.

(4) -Where an order pertains to land registered in the land registry it shall be deemed to be an instrument referred to in section 71 of The Land Titles Act.

s. 2 (s) - "subdivision" means a division of a parcel by means of a plan or subdivision, plan of survey, agreement or any instrument including a caveat, transferring or creating an estate or interest in part of the parcel.

s. 23-Where an instrument

(a) granting a lease or only part of a parcel, or

(b) charging, mortgaging or otherwise encumbering only part of a parcel, or

(c) providing for the sale of part of a parcel, has the effect or may have the effect of subdividing the parcel, the Registrar shall not accept the instrument unless it is approved in accordance with this Act and The Subdivision and Transfer Regulations.

s. 23a-(1) Where

(a) a plan of subdivision containing parcels of less than twenty acres in area has been registered in a Land Titles Office before the first day of July, 1950, and

(b) the title of two or more such parcels is evidenced by one certificate of titles,

the Registrar shall not accept an instrument that results or may result in more than one certificate of title in respect of those parcels, unless the instrument is approved by the approving authority.

(2)-The approving authority may refuse to approve an instrument referred to in subsection (1) if it will or may result in the issuance of separate certificates of titles to parcels having a frontage of less than the minimum requirements of the Subdivision and Transfer Regulations, and may require that the parcels be resurveyed or consolidated so as to create parcels or units of land with more adequate frontage, having regard to the requirements of The Subdivision and Transfer Regulations with respect to new subdivisions.

s. 25 (3)-Where the provisions of a reserve in part or in full is deferred, the Director as caveator may file a caveat respecting the deferred reserve against the title to the affected land in the land titles office.

ss. 28 to 52-Replotting provisions.

ss. 53 to 57 -Compulsory subdivisions.

s. 59 (1)-Where a subdivision of any land that is not subject to a zoning by-law is approved pursuant to The Subdivision and Transfer Regulations, the Director may, by means of a zoning caveat, regulate the uses to be made of the lots and parcels within the subdivision.

(2)-A zoning caveat shall

(a) set out a list of zones of permitted land use classes into which the land comprising the subdivision is divided.

(b) prescribe, prohibit and regulate uses of land and buildings within each zone in the same manner as may be done by means of a zoning by-law under this Act, 
Private Ditches Act. 1955 R.S.A. c. 241.

The Public Highways Development Act. 1966 S.A. c. 79.

Public Lands Act. 1966 S.A. c. 80. (c) be signed by the Director, and

(d) be filed by the Director in the land titles office when the plan of subdivision or transfer or other instrument affecting the subdivision is submitted for registration.

s. 5-The owners who may be made liable for the construction of a ditch under this Act are those owners whose lands lie within a distance of one mile from the sides and point of commencement of the ditch and any other owners whom the engineer may consider liable.

s. 31 (2)-Unless the owners within the municipality on notice pay the amounts for which they are made liable under section 30 the council may cause the amounts for which the owners are liable together with ten per cent added thereto to be placed on the tax roll.

(3) - Such amounts with the ten per cent added thereto

(a) become a charge against the lands of such owners respectively, and

(b) shall be collected in the same manner as taxes.

s. 21 (1)-The Minister and a city may enter into an agreement for the transfer by the city to the Crown in right of Alberta of title to any city street or for the purchase of land from the city for the purposes of a highway to be constructed and maintained by the Minister.

(2)-Notwithstanding anything in The City Act. the Minister may with the consent of a city purchase or expropriate land within the city for the purposes of a highway.

(3)-Where the title to a street or any land is vested in the Crown in right of Alberta pursuant to this section, the highway constructed thereon is subject to the direction, control and management of the Minister and not the city.

s. 5-Unless otherwise provided in this Act, every disposition made or entered into

(a) under the former Act or the regulations thereunder, or

(b) under The Provincial Lands Act or the Dominion Lands Act or the regulations under those Acts and relating to land,

and any renewal or re-issue thereof, is in every respect subject to this Act and the regulations made under this Act.

s. 6 (1)-Subject to subsection (2), the title to the beds and shores of all rivers, streams, watercourses, lakes and other bodies of water is hereby declared to be vested in the Crown in right of Alberta and no grant or certificate of title made or issued before or after the commencement of this Act shall be construed to convey title to such beds or shores.

(2)-Subsection (1) does not operate

(a) to effect any grant made before or after the commencement of this Act that specifically conveys by express description the bed or shore of any river, stream, watercourse, lake or other body of water, or any certificate of title founded on that grant, or

(b) to affect the rights of a grantee from the Crown or of any person claiming under him, where such rights have been determined by a court before June 18, 1931, or

(c) to affect the title to any land belonging to the Crown in the right of Canada.

s. 28 (1)-When any person is entitled to receive a title for an estate in fee simple to any public lands, a notification in Form $A$ in the Schedule shall be issued, which shall be

(a) signed by the Minister or Deputy Minister, and

(b) signed by the Director.

(2)-Before issue of the notification the fee payable under The Land Titles Act shall be paid to the Minister. 
(3)-The Minister shall forward the notification to the Registrar.

(4)-Where a certificate of title has not been issued by the Registrar for any public lands vested in or belonging to the Crown the Minister may issue a notification if Form $A$ in the Schedule in favour of the Crown in right of Alberta or of Canada.

(5)-When a notification is issued under subsection (4) it shall be forwarded to the Registrar who shall, without fee, forthwith issue a certificate of title.

s. 29-When a notification issues to or in the name of a person who is dead, the notification is not void for that reason but the title to the land thereby granted or intended to be granted vests in the personal representative of the deseased person as if the notification had issued to or in the name of the deceased person during his lifetime.

s. 32 (1)-All mines and minerals and the right to work the same are, by implication and without the necessity for any express words of expectation, excepted from every disposition and notification made under this Act.

(2)-The Minister in the case of any disposition or grant, or any kind of disposition, may direct that it shall be made subject to any reservation or exception that he may prescribe. ss. 118 to 123 deal with registration of assignments.

Public Trustee Act. 1955 R.S.A. c. 266.
Public Utilities

Board Act.

1960 S.A. c. 85 s. 10 (2)-The Public Trustee on the order of a judge of the Supreme Court may mortgage, lease, sell or otherwise dispose of any of the real or personal property of the missing person.

(3)-The Registrar of the land registration district within which the land of the missing person is situated

(a) on production of an instrument effecting a disposition of land referred to in subsection (2), and

(b) on production of a copy of or a certified copy of the order referred to in subsection (2),

shall deal with the instrument in the same manner as if the instrument were executed by the missing person.

s. 12 (1)-The Public Trustee is the committee of the estate of every mentally incompetent person who has no other committee.

s. 14-The Public Trustee while acting as committee of the estate of a mentally incompetent person may manage, handle, administer, sell, dispose of or otherwise deal with the estate of the mentally incompetent person to the same extent as could be done by that person if he were mentally competent. s. 20 (1)-Where a mentally incompetent person who is detained in an asylum, mental hospital or other public institution in another province has estate in this province, the Lieutenant Governor in Council may appoint an official of the other province who is charged with the duty of managing, handling, administering or caring for the estate of the mentally incompetent person therein to be administrator of his estate in this province.

s. 59 (1) - In the case of an order of the Board for payment of any money, costs, expenses or penalty, a certified copy of the order signed by the secretary may be registered in any land titles office in the province.

(2)-When so registered the order constitutes a lien and charge upon any land, or interest therein that is

(a) held by the party, person, company or corporation ordered to pay the money, and

(b) situate in the land registration district in which such office is situate

to the same extent and in the same manner as the lands would be bound by the registration of an execution issued after judgment in the Supreme Court of Alberta. 
(3)-The amount ordered to be paid by any order so registered may be realized in the same manner and by similar proceedings as the amount of any registered execution of the Supreme Court of Alberta.

s. 87 (1)-No owner of a public utility shall

(g)-without the approval of the Board,

(i) sell, lease, mortgage or otherwise dispose of or encumber its property, franchise, privileges or rights, or any part thereof, or

(ii) merge or consolidate its property, franchise, privileges or rights, or any part thereof, with that of any other owner of a public utility,

and every sale, lease, mortgage, disposition, encumbrance merger or consolidation made in contravention of this clause is void and of no effect, but nothing in this clause shall be construed to prevent in any way the sale, lease or other disposition of any of the property of any owner of a public utility in the ordinary course of his business.

Public Welfare Act. 1955 R.S.A. c. 286.

Public Works Act. 1965 S.A. c. 78. s. 48a (1)-Where a social allowance is provided to meet the payments of a land mortgage or an agreement for the sale of land the Minister may cause a caveat in Form $A$ in the Schedule to be registered in the land titles office against the certificate of title for the land.

(2)-On the registration of the caveat the Minister has a charge on the land equal to the amount of the payments made both before and after the registration of the caveat. (3)-On receiving the caveat the Registrar shall send a notice of the caveat to

(a) the mortgagee, where the payments are made for a mortgage, or

(b) the registered owner, where the payments are made under an agreement for sale.

(4)-A transfer of a mortgage or an assignment or an agreement concerning a mortgage or an agreement for sale on which payments have been made as mentioned in subsection (1) is of no effect without the written consent of the Minister. (5)-No caveat registered pursuant to this section shall be cancelled or withdrawn except by the Minister's request to withdraw the caveat.

(6)-No fees are payable to the Registrar for the registration or withdrawal of a caveat under this section.

(7)-The Minister may waive the rights given by this section in whole or in part, for the purpose of any proceedings or for any other reason he thinks is proper.

s. 2-In this Act,

(c) "public works" includes the undertaking and all the works and property that may be acquired, made, built, constructed, erected, extended, enlarged, repaired, maintained, improved, formed, excavated, operated, re-constructed, replaced or removed at the expense of the Crown or for which there is legislative authority to pay out or apply public moneys thereon otherwise than by way of subsidy only.

s. 14 (1)-Where

(a) a person provides labour, equipment, materials or services used or reasonably required for use in the performance of a contract with the Crown for the construction, alteration, demolition, repair or maintenance of a public work, and

(b) the contractor or a subcontractor does not pay that person in accordance with his obligation to do so,

that person may send a notice of his claim to the department, board, commission or agency of the Crown that is responsible
for the public work.

(2)-The notice of the claim

(a) shall be sent by registered mail not later than ninety days after the last day on which the labour, equipment, material or services were provided, and 
(b) shall set out the nature and amount of the claim against the contractor or subcontractor in a form satisfactory to the Crown.

s. 21 (1)-Land required for a public work shall be surveyed and marked on the ground by a qualified land surveyor or engineer who shall prepare a plan thereof.

(2)-Notwithstanding subsection (1), where any land required for a public work

(a) consists of a lot or parcel shown on a plan that is filed or registered under The Land Titles Act, or

(b) is the subject matter of one certificate of title, or consists of one or more legal subdivisions within the meaning of The Alberta Surveys Act,

the land need not be surveyed but the Director of Surveys shall prepare a notification describing the lot, parcel, land or legal subdivision and stating that it is required for a public work.

(3)-The deposit in the land titles office of a notification as provided in section 10 of The Expropriation Procedure Act shall, for the purposes of The Land Titles Act, be deemed to be the filing of a plan of the land.

s. 28 (1)-When a Public Works Development Area is created, the Minister shall file a copy of the order in council and a plan of the Public Works Development Area with

(a) the clerk or secretary-treasurer of the municipality, and

(b) the Registrar of Land Titles for the land registration district,

in which the Area is situated and shall give notice of the creation of the Area and of the provisions of this section to all owners of land in the Area,

(2)-The Registrar of Land Titles shall endorse upon every certificate of title to land within a Public Works Development Area, a notice that the land is within a Public Works Area and that this section applies in respect of that land.

s. 31 (2)-Title to property declared to be a public work under subsection (1) vests from the time of declaration in the Crown and that property shall be under the control of the Minister designated by the Lieutenant Governor in Council.

s. 32-Where any land is acquired by the Crown for a highway through agreement with the owner, title to the land may be registered in the name of the Crown by the filing of the plan or notification and it is not necessary to register a transfer of that land.

Quarries Regulation Act.

1955 R.S.A. c. 273. s. 6 (1)-The owner of a quarry shall not carry on quarrying operations at the quarry unless he is the holder of a permit entitling him to do so.

(2)-No person shall commence or recommence any quarrying operations unless he is the holder of a permit referred to in subsection (1) entitling such person to carry on quarrying operations.

(3)-An application for a permit to carry on quarrying operations and the permit itself shall be in the forms prescribed by the Minister.

s. 7-No quarrying operations shall be abandoned by the owner unless

(a) notice in writing of the intention to abandon the operations has been forwarded to the Director of Mines, and

(b) the consent in writing of the Director of Mines has been issued.

s. 8- Where there is a change in the ownership of a quarry or the manager of a quarry is changed, the new owner or the owner as the case may be, shall within ten days of the change advise the Director of Mines thereof in writing. 
Railway Act. 1955 R.S.A. c. 276.

s. 76-The plan, profile and book of reference when sanctioned shall be deposited in the Department and each plan shall be numbered consecutively in order of deposit and the company shall also deposit copies thereof, or of such parts thereof as relate to each land registration district through which the railway is to pass, duly certified as copies by the Minister, in the office of the Registrar for the land registration district or districts.

s. 78 (1)-Every Registrar of a land registration district shall receive and preserve in his office all plans, profiles, books of reference, certified copies thereof and other documents required by this Act, to be deposited with him and shall endorse thereon the day, hour and minute when they were deposited.

s. 85-The company shall not, unless they have been expressly purchased, be entitled to any mines, ores, metals, coal, slate, mineral oils, gas or other minerals in or under any lands purchased by it or taken by it under any compulsory powers given to it by this Act, except only such parts thereof as are necessary to be dug, carried away or used in the construction of the works, and all other mines and minerals shall be deemed to be excepted from the conveyance of the lands unless they are expressly named therein and conveyed thereby. (First appeared 1911-12 S.A. c. 15 s. 6-in force since 16th of February, 1912.)

s. 93-A copy of the duplicate of the map or plan and book of reference and application and the certificate shall be deposited in each of the land titles office of the land registration districts in which the lands lie.

s. 94 (1)-Upon the granting of the certificate the company may without the consent of the owners take the land shown on the map or plan and book of reference.

(2)-The company and all persons who could not otherwise convey the land to the company have with respect to any such land all the powers granted by this Act to companies and persons who cannot otherwise convey the land, with respect to lands that may be taken without the consent of the owners thereof, and all the provisions of law applicable to the taking of land by the company and its valuation and the compensation thereof apply to the lands mentioned in the certificate. s. 98 (1)-All tenants for life, guardians, executors, administrators and trustees and all persons whosoever, not only for and on behalf of themselves, their heirs and successors but also for and on behalf of those whom they represent, whether infants, unborn issue, lunatics, idiots or other persons seized, possessed of or interested in any lands, may, subject to subsection (2) contract for, sell, transfer and convey such lands or any part thereof to the company.

(2)-When such persons have no right in law to sell or convey the rights of property in the said land they may obtain from a judge after due notice to the persons interested the right to sell the land, and the judge shall give such orders as are necessary to secure the investment of the purchase money in such manner as he deems necessary in accordance with law to secure the interests of the owner of the land.

s. 99-Any contract, agreement, sale, conveyance or assurance so made hereunder is valid and effectual in law to all intents and purposes whatever and vests in the company receiving the same the fee simple or other estate therein conveyed in the lands therein described free and discharged from all trusts, restrictions and limitations whatever and the person so conveying is hereby relieved from liability for what he does by virtue of or pursuant to this Act.

Real Estate Agent's Licensing Act. 1955 R.S.A. c. 279. s. 29-No agent or salesman shall purchase for himself either directly or indirectly real estate listed with him for sale, nor shall he acquire any interest therein either directly or indirectly, until he has clearly disclosed to the listing owner complete details of his negotiations for the sale of the said property to another person. 
Religious Societies Lands Act.

1955 R.S.A. c. 285.
Right of Entry Arbitration Act. 1955 R.S.A. c. 290. s. 3-The trustees shall within twelve months after the execution of the transfer or deed of conveyance cause the title to the land described therein to be registered in the land titles office of the land registration district in which the land is situated otherwise the deed or transfer is void.

s. 8 (1) - When it becomes unnecessary to retain land held by trustees for the use of a religious society or congregation and it is deemed advantageous to sell it, the trustee for the time being

(a) may give public notice of an intended sale, specifying the premises to be sold, the terms of payment and the time of sale, and

(b) after publication of the notice not less than once in each week for four successive weeks in a newspaper published in or near the place where the land is situated, may sell the land by public auction in accordance with the notice.

s. 9-Before a transfer is executed pursuant to a public or private sale the religious society or congregation for whose use the land is held shall be notified and the sanction of a judge of the Supreme Court exercising jurisdiction in the judicial district in which the land is situated shall be obtained for the execution of the transfer.

s. 22-Instruments dealing with the property of the congregation

(a) shall be executed under the corporate seal, and attested by the signature of not less than two officers thereof, and

(b) shall have endorsed thereon or attached thereto an affidavit by some other officer of the congregation capable of swearing positively to the fact that the execution of the instrument was authorized by the congregation at a meeting thereof duly called for the purpose, and the affidavit may be in Form $\mathbf{C}$ in the Schedule.

s. 24 (1)-Where any congregation that has previously acquired lands or other property, the title to which is vested in trustees, becomes incorporated pursuant to this Act the trustees of the congregation, or in the case of the death or removal of any of the trustees, a majority thereof, may execute a transfer of the church property to the congregation in the corporate name thereof.

(2)-The transfer of such property shall be registered without further or other proceedings, and the land thereupon becomes and is vested in a body corporate for the purposes of the congregation in question, subject to the provisions of this Act.

s. 12 (1)-No operator has a right of entry user or taking of the surface of any land for

(a) the removal of minerals contained in or underlying the surface of such land or for or incidental to any mining or drilling operations,

(b) the laying of pipe lines for or in connection with any mining or drilling operations, or the production of minerals, or

(c) the erection of tanks, stations and structures for or in connection with a mining or drilling operation, or the production of minerals, until the operator

(d) has obtained the consent of the owner of the surface of the land, or has become entitled with respect to the interest of the owner, to entry by reason of an order of the Board, and

(e) has obtained the consent of the occupant, if any, of the surface of the land, or has become entitled with respect to the interest of the occupant, to entry by reason of an order of the Board.

(2)-Notwithstanding anything contained in a grant, conveyance, lease, licence or other instrument, whether made before 
or after the coming into force of this Act, and pertaining to the acquisition of an interest in a mineral, an operator thereby does not obtain the right of entry, user or taking of the surface of any land unless the grant, conveyance, lease, licence or other instrument provides a specific separate sum in consideration for the right of entry, user or taking of the surface required for his operations, but this subsection does not apply in a case where the operator, prior to the first day of July, 1952, has for any of the purposes referred to in subsection (1) exercised the right of entry, user or taking of the surface of land in accordance with the provisions of a grant, conveyance, lease, licence or other instrument.

s. 22 (2)-An order of the Board or a certified copy thereof may be filed with the Registrar of the appropriate land registration district who, in payment of the proper fee, shall make an entry of the order filed on the certificate of title to the land affected.

(3)-Where a certificate of title to land is endorsed with a memorandum of the registration of an order of the Board and a notice is given to the Registrar of the land registration district by a member of the Board stating that no part of the land described in the certificate is, according to the records of the Board, affected by the order referred to in the memorandum, the notice may be registered by the Registrar, without fee, and upon registration, the endorsement of the memorandum on the certificate of title shall be cancelled.

s. 32-Where there is a conflict between the provisions of this Act and anything contained in any grant, conveyance, lease, licence or other instrument, whether made before or after the coming into force of this Act with respect to the right of entry, user or taking of the surface of any land incidental to any mining or drilling operaitons, the provisions of this Act prevail.

Rural Electrification Revolving Fund Act. 1955 R.S.A. c. 291. s. 17 (1)-Within thirty days after a loan is approved by the Supervisor of Co-operative Activities the Supervisor shall cause a notice of the lien note in Form B in the Schedule to be filed in the office of the land titles office in the district in which is situated the land for which the association holds a a lien note.

(3)-Upon receiving notice in writing in Form $D$ in the Schedule from the Supervisor of Co-operative Activities that a lien note in respect of which a memordanum has been endorsed against the title of any land has been discharged by a member, the Registrar of Land Titles shall without fee cancel the memorandum on the title to the land.

(5)-Notwithstanding the provisions of The Tax Recovery Act, or The Irrigation Districts Act as the case may be a lien filed in respect of land or an interest in land under this Act continues to be an encumbrance against that land registered in the name of a subsequent owner or owners to the same extent as if proceedings had not been taken under The Tax Recovery Act or The Irrigation Districts Act as the case may be. s. 18. (1)-When a notice in Form $B$ in the Schedule is filed,
the association has a lien

(a) upon the land of the member to which electricity is to be conveyed,

(b) upon the interest of the member in the land to which electricity is to be conveyed, or

(c) upon the land or the interest in the land of the member in respect of which the association holds a lien as provided by subsection (2) of section 9 ,

as the case may be, to the amount of the lien note of the member held by the association, and the lien has the same priority as if it were a mortgage under The Land Titles Act to secure the total amount of the note of the member and registered in the proper land titles office at the time at which the notice referred to in section 17 was filed in such land titles
office. 
(2) - Land in respect of which notice of a lien note has been filed shall, for the purposes of this Act, been deemed not to be a homestead within the meaning of The Dower Act.

Rules of the Supreme Court of Alberta. Consolidated-1962.

Rule 391-Every writ of fieri facias shall be issued against both goods and lands of the debtor.

Rule 474-An adult person entitled to compel partition of land or any estate or interest therein may on notice to one or more of the persons entitled to a share therein apply to a judge for partition or sale, and the judge may make such order for partition or sale or such other order as may seem just.

Sand and Gravel Act. 1955 R.S.A. c. 296.

School Act.

1955 R.S.A. c. 297. at all times to have been the owner of and entitled to sand and gravel on the surface of that land, and all sand and gravel obtained by stripping off the overburden, excavating from the surface, or otherwise recovered by surface operations.

s. 4-(1) The sand and gravel referred to in section 3 shall be deemed not to be a mine, mineral or valuable stone but shall be deemed to be and to have been a part of the surface of land and to belong to the owner thereof.

(2) Notwithstanding any patent, title, grant, deed, notification, conveyance, lease, licence, agreement, disposition or other document, issued or made before or after the seventh day of April, 1951, and that contains or reserves mines, minerals or valuable stone, the owner of the mines, minerals or valuable stone in any land is not entitled to the sand and gravel in that land referred to in section 3 as against the owner of the surface of the land.

s. 31 (1)-Upon any inclusion, exclusion or transfer of lands or districts being made under the provisions of this Act, the s. 3-The owner of the surface of land is and shall be deemed Minister, if he considers any adjustment of assets and liabilities necessary, shall in the same or a subsequent order give such directions as to him may appear proper with respect to the assets and liabilities of any district or division affected by the inclusion, exclusion or transfer, and the directions are binding upon the board of any such district or division.

(2) In order to give effect to any directions issued under subsection (1), the Minister, by order, may

(a) make provisions for the assessment of property in a district or division and for the levying and collection of taxes on that property, and

(b) execute a transfer of real property under The Land Titles Act from any board to another, and the Registrar of Land Titles for the proper land registration district shall register the transfer without the charge of assurance fund fees and shall issue a certificate of title to the property in the name of the transferee.

s. 45-(1) Notwithstanding anything contained in section 43 or 44, upon the dissolution of a consolidated school district, the Minister, by order, may in such manner as he deems proper, distribute the assets and liabilities of the consolidated school district between or among the several districts included in the consolidated district prior to its dissolution.

(2) If any such district is or has been included in a division the assets and liabilities of the consolidated district allocated by the order of the Minister to any such district shall be deemed to have been vested in the division from the date of the order including the district in the division.

s. 74-In each district, unless otherwise provided by this Act, there shall be a board of trustees, and the members of the board are a corporation under the name of "The Board of Trustees ... School District No. ..." and shall have a common seal.

s. 76-(1) Subject to the provisions of section 39, the board of a division shall consist of one trustee for each subdivision.

(2) The members of the board of a division are a corporation under the name of "The Board of the ... School Division No. ..." and shall have a common seal. 
Securities Act, 1955. 1955 S.A. c. 64 .

Seizures Act. 1955 R.S.A. c. 307 s. 211-The board of a non-divisional district or of a division

(a) shall take possession and have the custody and safekeeping of the property of the district or division, and

(b) may dispose of any property real or personal belonging to the district or division but the disposal of any land or building used for the instruction or accommodation of pupils is subject to prior approval of the Minister.

s. (2) $\mathrm{r}$ - "Security" includes

(ii) any document constituting evidence of title to or interest in the capital, assets, property, profits, earnings or royalties of any person or company.

(vi) without in any way restricting the generality of anything hereinbefore contained,

(I) any documents evidencing a fractional undivided interest in any oil, gas or mining lease, permit, reservation or claim, or where it is a part of a common enterprise for profit, in any leasehold or real property,

whether any of the foregoing relate to a person, proposed company or company, as the case may be:

s. 3 (1)-This Act does not apply

(a) to any power of distress under any trust, deed, mortgage or similar instrument made to secure any debentures, stocks, bonds or other securities of a body corporate, nor to any distress thereunder.

s. 5 (1)-By virtue of a writ of execution the sheriff charged with the execution thereof may seize and sell any equitable or other right, property, estate, interest of the debtor in or in respect of any goods or other personal property and any equity of redemption of the debtor therein, and also any leasehold interests in land and any other chattels real that are the property of the debtor.

s. 8 (1)-A sheriff charged with the execution of a writ of execution may seize thereunder any registered mortgage of or encumbrance on lands or chattels of which the debtor is the owner, by delivering a notice in writing of the seizure to the proper officer in the office in which the mortgage or encumbrance is registered.

s. 8 (2)-No mortgage or encumbrance is affected or charged by any writ of execution until delivery of the notice.

(3) Upon receipt of any such notice by the proper officer, he shall make an entry thereof in the register or other book in which the mortgage or encumbrance is registered, and the proper officer is entitled to receive a fee of one dollar for so doing.

(4)-No person who is liable to pay any money under any mortgage or encumbrance seized pursuant to this section is affected by the seizure thereof until

(a) notice in writing of the seizure has been served upon him personally, or

(b) he has otherwise acquired actual knowledge of the seizure.

(5) - Any payments made by that person to the debtor after service of the notice of the seizure or after acquiring actual knowledge of the seizure are of no effect as against the sheriff and the creditor.

s. 9-No mortgage or other security for money seized under a writ of execution shall be sold except upon the order of a judge and then only upon such conditions as the judge thinks fit to prescribe.

s. 15 (1)-No sale of lands shall, unless a judge otherwise orders, be had under a writ of execution

(a) until after a return nulla bona in whole or in part, and 
(b) until after the expiration of one year from the date of the receipt by the Registrar of the appropriate land titles office of the copy of the writ of execution.

(2)-No lands shall be sold under a writ of execution until after the giving of such notice of the sale by advertising or otherwise as may be directed by a judge.

(3)-When at any sale by auction held by a sheriff of land taken in execution

(a) there are no bidders, or

(b) the sheriff receives for the land no bid that he deems sufficient,

the sheriff may from time to time adjourn the sale to a date to be subsequently fixed by the sheriff and either to the same or a different place, and in any other case, notice of the adjourned sale shall be given in the manner prescribed by section 14.

(4)-If the amount authorized to be made and levied under a writ of execution is made and levied thereunder out of goods and chattels, the person issuing the writ is not entitled to the expenses of any advertising of lands thereunder.

s. 20-The right of a mortgagee of land or his assigns to distrain for interest in arrears or principal due upon a mortgage shall, notwithstanding anything stated to the contrary in the mortgage or in any agreement relating to the mortgage, be limited

(a) to the goods and chattels of the mortgagor or his assigns, and

(b) to only such goods and chattels as are not exempt from seizure under execution.

Societies Act. 1955 R.S.A. c. 315

Special Areas Act. 1964 S.A. c. 87. s. 4-Five or more persons may become incorporated under this Act for any benevolent philanthropic, charitable, provident, scientific, artistic, literary, social, educational, agricultural, sporting or other useful purpose, but not for the purpose of carrying on a trade or business.

s. 18 (1)-A society may acquire and take by purchase, donation, devise or otherwise all kinds of real estate and personal property, and may sell, exchange, mortgage, lease, let, improve and develop the same, and may erect and maintain any necessary buildings.

s. 19 (1)-For the purpose of carrying out its objects, a society may borrow or raise or secure the payment of money in which manner as it thinks fit, and in particular by the issue of debentures.

s. 10-Notwithstanding the provision of any other act, any lands within a special area, the title to which for the time being is registered in the name of any municipality in the proper land titles office, are hereby transferred to, and the title thereto vested in the Minister on behalf of the Crown. s. 12-Every public road, highway, street and lane in a special area is subject to the direction, control and management of the Minister.

s. 15-No public lands situated in a special area shall be sold, leased or otherwise disposed of without the consent of the Minister of Municipal Affairs.

s. 22-When an exchange of privately owned land for public land is effected by the Minister and there are no encumbrances other than arrears of taxes or municipal or Provincial liens on the privately owned land, such encumbrances or any part thereof may be transferred to the public land so exchanged, and when any transfer of arrears of taxes is made the same shall be added to, and become part of the taxes payable for the current year in respect of the land last mentioned.

s. 26-If any conflict arises between any of the provisions of this Act and any of the provisions of any other Act, the provisions of this Act prevail. 
Succession Duty Act. 1955 R.S.A. c. 324.
Repealed by 1962 S.A. c. 86.

Still effective for all persons who died between 31st August 1905 and 1st April, 1947.

s. 11 (1)-The duty payable in respect of any property under this Part, together with interest thereon as provided in Part IV, constitutes a lien and charge in favour of the Crown in the right of the Province on and against that property.

(2)-The lien and charge

(a) has priority over all other claims of any person except claims secured by liens, charges or encumbrances on the property that were

(i) registered and subsisting at the date of death of the deceased, or

(ii) existing at the date of death of the deceased and and valid without registration,

(b) binds the property from the death of the deceased until the duty payable in respect thereof has been paid in full,

but the lien and charge does not attach to or bind any property that is transferred to a bona fide purchaser for value without notice of the lien or charge.

s. 21-Every person to whom property passes on death for any beneficial interest in possession or expectancy is liable for the duties in respect of so much of the property as passes to him and that is dutiable in the Province in accordance with the provisions of this Act.

s. 43-Notwithstanding the fact that security by way of bond or otherwise has been given to secure the due payment of succession duties pursuant to The Succession Duties Act, being Chapter 28 of the Revised Statutes of Alberta, 1922, The Succession Duties Act, 1932 being Chapter 16 of the Statutes of Alberta 1943, The Succession Duty Act, 1934, being Chapter 17 of the Statutes of Alberta, 1934, The Succession Duty Act, being Chapter 57 of the Revised Statutes of Alberta, 1942, or this Act, the lien given under the provisions of such Acts remains in full effect until all succession duties and interest levied in respect of the property covered by the lien have been paid, but the lien does not attach to any property that has been transferred to a bona fide purchaser for value without notice of the lien.

s. 48 (1)-Where any property of any person that has before his death been conveyed or transferred to some other person is declared liable to duty, the Court in an action or on summary application may declare the duty to be a lien upon the property and may make such declaration although the amount of the duty has not been ascertained.

(2)-Where such property, had it remained in the hands of the person to whom or for whose benefit it was conveyed or transferred by such deceased person, would have been liable for duty, but has been conveyed or transferred to any purchaser for valuable consideration, the Court may direct the person to whom or for whose benefit the property was conveyed or transferred by the deceased person to pay the amount of the duty to which the property would have been subject.

s. 60-Registration of any notice has the same effect as to priority as the registration of any instrument under The Land Titles Act.

s. 67 (1)-A Registrar of Land Titles shall not register a discharge of mortgage signed by the personal representative of a deceased person acting on a grant of letters probate not issued out of a court in the Province without the consent of the Minister, or until the Registrar is satisfied that duty in respect of the mortgage has been paid.

(2)-A Registrar of Land Titles, upon ascertaining that an interest in land, mortgage or encumbrance, passes on death by survivorship to a person, shall notify the Minister forth- 
with, and shall refuse to act upon the passing until the consent of the Minister is obtained or until the Registrar is otherwise satisfied that the duty in respect of the land, mortgage or encumbrance has been paid.

Alberta Surveys Act. 1955 R.S.A. c. 327. s. 28-Every township, section, or other authorized subdivision, town, village, block, lot, or parcel of land, shall consist of the whole width included between the several monuments placed as aforesaid, at the several corners thereof, and no more or less, notwithstanding any quantity or measure expressed in the official plan, certificate of title, grant or other instrument.

s. 32-The Minister shall, as soon as possible after the confirmation thereof, cause to be transmitted to the Registrar of every land registration district, to be lodged or filed with the Registrar a copy.

(a) of the official plan of the survey or re-survey of each township, settlement, town or village, site, lot, plot, or other survey or re-survey made under the authority of this Act, and

(b) of each plan of provincial lands amended or corrected under the authority of this Act in such land registration district.

s. 33-Whenever a surveyor is employed to make a subdivision survey, the surveyor

(a) shall first re-establish and carefully survey such part of the original outlines of any section, quarter section, settlement lot or other surveyed parcel of land as is necessary to establish properly the boundaries of the land to be subdivided, and

(b) shall then establish the block corners on the outlines of the land to be subdivided, or if it is intended that there are to be no block corners on the outlines he shall establish those block corners adjacent thereto and shall subsequently determine the interior block corners of his survey in reference to the block corners first established.

s. 44-Notwithstanding anything to the contrary in this Act in all cases where the provisions in respect of the re-establishment of lost monuments are found inapplicable, the surveyor shall proceed in such manner as to carry out the evident intention of the original survey as shown on the registered plan of the same.

s. 45-In subdivision surveys, plans of which were registered before the sixteenth day of February, 1912, any original monument or post marking a corner of a block, lot, street, lane, park or other point of survey, the original position of which can be in any way satisfactorily established, shall determine the true and unalterable position on the corner, whether, upon admeasurement on the ground, it is shown to agree with the measurements marked on the plan or not. s. 57 (1)-Where traverse surveys are required to determine the boundaries of a parcel of land fronting on a lake, river, stream or other flooded area, or to determine the boundaries of a reservoir or any flooded area, the surveyor shall plant iron posts

(a) at the beginning and end of the traverse, such points being fixed on lines that have been determined astronomically or upon previously surveyed lines, the information of which is on record,

(b) at the intersection of the traverse line with the posted boundaries of each road allowance, or where there is no road allowance of each section, settlement lot, or other surveyed parcel of land, and

(c) at such other points as may be deemed necessary.

(2)-All measurement shall be made with reference to the iron post so established.

(3)-The iron posts shall be driven into the ground to within four inches of the top. 
Tax Recovery Act. 1955 R.S.A. c. 334.

Alberta Government Telephones Act. 1958 S.A. c. 85. s. 58-In determining boundaries under this section

(a) offsets shall be made every one hundred feet and at less intervals if the nature of the case demands,

(b) all traverse lines and offsets shall be actually measured and complete angular measurements taken, and

(c) complete ties shall be taken connecting the band and traverse with any other survey of a permanent nature that may be affected.

s. 59-All plans of surveys under Sections 57 and 58 , shall clearly show all the angular and linear measurements defining them, the position and lengths of all offsets, and also whether the bank, centre of stream, high water line or other line forms the boundary, and such other information as may be of service in order that a clear and accurate interpretation of the survey can be arrived at.

s. 5 (2)-Where a tax recovery notification or caveat has been placed upon the title to a parcel pursuant to the provisions of any Act for the recovery of taxes, the Registrar, until the notification or caveat is removed, shall not cancel the certificate of title to the parcel or to any part thereof without the consent of the treasurer of the municipality at whose instance the notification or caveat was so placed, save and except only upon the devolution of the title thereto by the operation of law.

All other sections relevant and to lengthy to summarize.

Former Acts-1900 North West Territories Ordinance c. 10.

1901 North West Territories Ordinance c. 12

1905 Consolidated Ordinance c. 109.

1919 S.A. c. 20 (Notice of Sale Act).

1922 S.A. c. 25.

1922 R.S.A. c. 122

1929 S.A. c. 39 .

1938 S.A. c. 82

1942 R.S.A. c. 162

See also Taxation Provisions in other municipal and School Acts and various City Charters.

The School Assessment Ordinance -1905 Cons. Ord. c. 105.

The Local Improvement Act -1907 S.A. c. 11 ss. 91-96.

The Rural Municipality Act -1911-12 S.A. c. 3 ss. 303-320.

The Village Act

The Town Act

$$
-1913 \text { S.A. c. } 5 \text { ss. 127-138. }
$$

-1911-12 S.A. c. 2 ss. 324-335.

Charters for Cities of Calgary, Edmonton, Medicine Hat until 1951 S.A. c. 9 - City Act.

s. 18 (1)-The commission

(a) may at any time enter upon and take, or use, any lands in whomsoever vested, and

(b) has full power and authority to do on or in relation to any real or personal property all acts and things that it deems necessary, advisable or expedient to do in order to carry out any authority or power conferred upon it by this Act.

(2)-The commission may expropriate, purchase, lease or otherwise acquire land that it deems necessary, advisable or expedient to acquire in order to carry out any authority or power conferred upon it by this Act.

(3)-For the purpose of expropriating land the commission has the same powers and may proceed in the same manner as the Minister of Public Works under the Expropriation Procedure Act, relating to the expropriation of land.

s. 32 (1)-All land, plant, supplies, buildings, works, rights, contracts, franchises, easements, assets, liabilities and property of every kind, including things in action and causes of 
Temporary Restriction on Alienation of Mines and Minerals Act. 1955 S.A. c. 67. action, owned, held, incurred or used by the Government of Alberta for the purposes of and in connection with the system owned and operated by the Government and commonly known as the Alberta Government Telephones or the Alberta Government Telephones System are hereby transferred to and vested in the commission.

(2)-The Lieutenant Governor in Council may, by order, specify the lands that are vested in the commission by subsection (1) and thereupon the Registrar of the appropriate land titles office shall register the commission as the holder of an estate in fee simple in the lands so specified as if such order were a notification or a registerable transfer, as the case may require.

s. 2 (1)-A person who acquired any mines and minerals as a result of an error in the Iand Titles Office and who did not acquire them bona fide for value without notice of the error shall not dispose of the mines and minerals, or any interest therein, by way of transfer, sale, mortgage, assignment, agreement, lease or otherwise.

(2)-Any disposition made in contravention of subsection (1) is void.

s. 3-Notwithstanding section 167a of The Land Titles Act, the Registrar may refuse to issue a mineral certificate where a purported disposition of mines and minerals may be void under this Act, and thereafter section 172 of The Land Titles Act applies.

s. 4-This Act shall not be construed so as to prevent transmission of mines or minerals to the personal representative of a deceased owner.

(NOTE: This Act was in force from the 23rd of February, 1955 until 1st of July, 1958.)

Town and Village Act. s. 38 (1)-The mayor, councillors and electors of any town 1955 R.S.A. c. 338. and village in the Province and now or hereafter created, established or formed continue to be and are a body corporate and subject to all the liabilities of a corporation.

(3)-The body corporate is capable of acting by the council, and the council shall exercise all powers vested in the corporation by this Act or otherwise.

s. 266-The title to all public roads, highways, streets and lanes in a town or village are vested in the Crown in the right of the Province.

s. 267 (1)-Subject to the Water, Gas, Electric and Telephone Companies Act and The Pipe Line Act, 1958, and to section 268 of this Act, every public road, highway, street and lane shall be subject to the direction, control and management of the council of the town or the village in which it is situated. (2) Subsection (1) shall be deemed to have reference only to the property in the surface of a public road, highway, street or lane and in so much of the actual soil below and the air above the same as reasonably may be required for its control, protection and maintenance as a highway for the use of the public.

s. 269 (1)-The council, subject to the approval of the Minister of Highways, may pass a by-law for the purpose of closing a public street, lane, road or highway.

s. 273 (1) - A council may pass a by-law authorizing the purchase, lease, or other acquisition of land and the improvements thereon if any, within or without the town or the village or of an interest therein,

(a) for the purpose of erecting municipal offices or other buildings essential to the municipal administration,

(b) for the purpose of erecting a lock-up, weight-house, market, community hall, skating rink, curling rink, swimming bath, public library, museums or art galleries,

(b1) for recreational or cultural facilities, 
(c) for a public park, walk, parking space, tourist camp, trailer court, exhibition ground or recreation ground,

(d) for a nuisance ground,

(e) for a cemetery,

(f) for a quarry, gravel or sand pit,

(g) for the purposes of a ferry,

(h) for use as a highway, road, street, alley, by-way, or for the construction of a bridge,

(i) for the purposes of preventing the operation of any or all coal-mines or coal pits within, upon or under a part of the town or village,

(j) for the purpose of acquiring, erecting, constructing or installing any works, wells, buildings, dams, tanks, pipes, machinery, plant or equipment necessary for or incidental to the provision of a public utility.

s. 278 (1)-A council may acquire by gift

(a) from the Crown in the right of Canada or from the Soldier Settlement Board land situate within the boundaries of the town or the village, and

(b) from any person land that is situate within the town or the village and is, at the time of transfer, free from all encumbrances whatsoever.

(2)-A council may, under an order of the Local Authorities Board cancelling a plan of subdivision, acquire lands situate within the boundaries of the town or village.

(3)-Any parcel of land acquired pursuant to subsection (2) shall continue to be assessed from the date of acquisition by the town or the village and the taxes payable to the town or the village and to a school district that collects its own taxes in respect thereof shall continue to be charged against the parcel in the manner prescribed by section 24 of The Tax Recovery Act and in case the parcel is sold or leased the proceeds of the sale or lease shall be dealt with and distributed in the manner prescribed by section 27 of The Tax Recovery Act.

(4)-Land acquired pursuant to this section may be sold, leased, or otherwise disposed of in such manner and at such times and under such terms and conditions as the council, by resolution from time to time, may prescribe.

s. 283-If a council desires for any purpose authorized by this Act to acquire land included in a plan of subdivision registered in a Land Titles Office, except those purposes authorized by subsection (3) of section 273 , and if it cannot acquire the land at a fair price by agreement with the owner and occupier thereof or other persons interested therein, it may acquire the land by expropriation in the name and on behalf of the town or the village, but excepting thereout all mines and
minerals.

s. 283a-(1) A council may expropriate land not included in a plan of subdivision registered in a land titles office,

(a) if the land is required for any purpose authorized by this Act, other than the purposes authorized by subsection (3) of Section 273, or

(b) if the land is necessary for the use, construction, maintenance or repair of a work authorized by this Act, or for obtaining better access thereto.

(2) -The land to be acquired shall be surveyed and marked on the ground by a qualified surveyor who shall prepare plans in triplicate of the land.

(3)-The plans shall be certified by the surveyor in the form set out in Form 33 in the Schedule, and by the secretarytreasurer in Form 34 in the Schedule, and shall be approved by the Director of Surveys who shall forward the plans to the proper land titles office.

s. 283a (4)-After having filed the plans the Registrar of Land Titles

(a) shall forward one of the plans of survey to the Department of Highways and one to the secretarytreasurer, and 
(b) shall furnish the council with a statement of all fees payable in connection with the filing.

(5)-The council shall forthwith pay the fees mentioned in subsection (4).

(6)-The provisions of The Land Titles Act, with the necessary changes being made, apply with respect to a plan filed under this Act.

s. 297a-Where, through agreement with the owner, a council acquires land for the purpose of a highway, road, street, lane, bridge, culvert, drain or ditch, title to the land may be vested in the Crown in right of the Province by filing in the proper land titles office,

(a) plans of survey in accordance with section 297, and

(b) an affidavit of the secretary-treasurer setting forth a description of the land, and that agreement has been reached with all the owners thereof as to the land to be acquired and the price to be paid, and it is not necessary to register a transfer of the land. s. 299-Subject to the provisions of The Tax Recovery Act, a council may provide for the selling, leasing or otherwise disposing of lands finally acquired by the town or the village under provisions of any statute that provides or provided for the recovery of taxes.

s. 377 (1)-The taxes and costs due in respect of any land may be recovered with interest as a debt due to the town or the village from a person who was the owner, conditional owner or purchaser of the land at the time of its assessment or subsequently because the owner, conditional owner, or purchaser of the whole or any part thereof saving his recourse against any other person and the taxes and costs are a special lien on the land, if the land is not exempt from taxation by the Province, in priority to every claim, privilege, lien or encumbrance of every person except the Crown, and the lien and the priority are not lost or impaired by any neglect, omission or error.

Transfer and Descent of Land Act. 1955 R.S.A. c. 342.

Treasury Branches Act.

1955 R.S.A. c. 344. s. 8 (1)-No words of limitation are necessary in any transfer or conveyance of any land in order to transfer all or any title therein, but every instrument transferring land operates as an absolute transfer of all such right and title as the transferor has therein at the time of its execution, unless a contrary intention is expressed in the transfer or conveyance.

(2)-Nothing in this Act precludes any transfer from operating by way of estoppel.

(3)-Hereafter any words of limitation used in any transfer, conveyance or devise of land have the like force and meaning as the same words used by way of limitation of personal estate.

s. 9-When, by any letters patent, transfer, conveyance, assurance, will or other assignment, land or any interest in land is granted, transferred, conveyed, assigned or bequeathed to two or more persons, other than as executors or trustees, in fee simple or for any less estate, legal or equitable, such persons take as tenants in common and not as joint tenants unless an intention sufficiently appears on the face of the letters patent, transfer or conveyance, will or other assurance that they should take as joint tenants.

s. 6 (4)-Subject to the terms and provisions of any contract existing on the tenth day of January, 1941, or to any regulations made pursuant to this Act, the Minister, either himself or by his duly authorized agents,

(a) may loan any deposits received in the branches of the treasury under the provisions of this Act to persons, firms or corporations upon such terms as may be agreed upon, and

(b) in connection with any such loan may take such negotiable instruments and securities as he may from time to time direct. 
Trustee Act. 1955 R.S.A. c. 346 .

Ultimate Heir Act. 1955 R.S.A. c. 348.

Unconscionable Transactions Act. S.A. 1964 c. 99.

s. 24-Where a power or trust is given to or vested in two or more trustees jointly then unless the contrary is expressed in the instrument if any, creating the power or trust it may be exercised or performed by the survivor or survivors of them for the time being.

s. 45-Where there are several executors administrators, or administrators with will annexed and one or more of them die the powers hereby created vest in the survivor or survivors.

\section{s. 2-In this Act}

(a) "ultimate heir" means the person entitled to take by descent or distribution the property of whatsoever nature of an intestate in the event of failure of heirs or next of kin entitled to take such property by the law heretofore in force;

(b) "university" means the body corporate known as the Governors of the University of Alberta.

s. 4-The words "heir" "heirs" or "next of kin" in any document transferring land situate in the Province, or giving or evidencing title thereto shall be construed by all courts and judges in the Province as including the University, but only after all other heirs or next of kin.

s. 7-Where no claimant has commenced an action in the Province within six years from the death of the intestate to dispute the claim of the University, then the University shall be deemed to be the sole heir and next of kin of the intestate and thereafter no action shall be brought to question the right of the University as sole heir and next of kin of the intestate.

\section{s. 2-In this Act,}

(a) "cost of the loan" means the whole cost to the debtor of money lent, and includes interest, discount, subscription, premium, dues, bonus, commission, brokerage fees and charges, but does not include registration or filing fees prescribed by or pursuant to any statute;

(b) "money lent" includes money advanced on account of any person under a mortgage or in any transaction that, whatever its form may be, is substantially one of money-lending or securing the repayment of money so advanced.

s. 3-Where, in respect of money lent, the court finds that, having regard to the risk and to all the circumstances, the cost of the loan is excessive and that the transaction is harsh and unconscionable, the court may

(a) reopen the transaction, take an account between the creditor and the debtor, and relieve the debtor from payment of any sum in excess of the sum adjudged by the court to be fairly due in respect of the principal and the cost of the loan;

(b) notwithstanding any statement or settlement of account or any agreement purporting to close previous dealings and create a new obligation, re-open any account already taken and relieve the debtor from payment of any sum in excess of the sum adjudged bv the court to be fairly due in respect of the principal and the cost of the loan;

(c) order the creditor to repay any excess if the same has been paid or allowed on account by the debtor;

(d) set aside either wholly or in part or revise or alter any security given or agreement made in respect of the money lent, and, if the creditor has parted with the secruity, order him to indemnify the debtor.

Urban Mining Operations Act. 1955 R.S.A. c. 353. s. 5 (1)-Notwithstanding anything to the contrary contained

(a) in any statute, and

(b) in any transfer, deed, agreement, contract or any other instrument,

no coal underlying or subjacent to any land that is the site of any highway, street, lane or public place within the corporate 
Utilization of Lands and Forests Act. 1955 R.S.A. c. 354.

Water, Gas, Electric and Telephone Companies Act. R.S.A. 1955 c. 361.

Water Resources Act. 1955 R.S.A. c. 362 . limits of any city, town or village shall be mined, worked, disturbed or removed in any way whatsoever until the use of the underlying surface as a highway, street, lane, or public place is permanently discontinued.

s. 9 (1)-When the required notice of an order under section 8 has been given, the Minister may issue a notice describing the controlled land or setting out the limits of the controlled land.

(2)-The notice shall be filed in the office of the Registrar of Land Titles of the land registration district in which the controlled land is situated.

(3)-The Registrar of Land Titles, upon receipt of the notice, shall endorse upon the appropriate certificate of title a memorandum that the use of the land mentioned in the notice is controlled under this Act.

s. 30 (1)-Where a company desires or proposes to acquire any lands or any interest in lands situate outside the limits of a city, town, or village for a right of way for any of its mains, pipes, wire, conductors, poles or other devices that are required for conveying, transmitting, supplying or distributing its gas, water or electricity or its telephone or sewage services, which are hereinafter referred to as the "works", the company shall first make application to the Minister for approval of the intended route of the right of way.

(2)-The company shall forward with its application for approval of the intended route of the right of way such plans and other information as the Minister may from time to time prescribe.

(3)-Upon considering the application the Minister shall have regard to all the circumstances that appear to him to be relevant and in particular, but not so as to limit the generality of the foregoing, shall have regard to

(a) the recommendations, if any, of the Director of Surveys or the Alberta Power Commission, as the case may require,

(b) the objection of an interested party,

(c) any public interest that, in the opinion of the Minister might be affected by the granting or refusal of his approval, and

(d) the needs and general good of the residents of the Province,

(4)-The decision of the Minister as to whether a person is or is not an interested party within the meaning of clause (b) of subsection (3) is final.

s. 8(1)-Except in pursuance of a valid agreement or undertaking existing on the first day of April, 1931, no grant shall be made by the Crown of lands or of any estate therein, in such terms as to vest in the grantee any exclusive right or privilege with respect to any water or any exclusive or perpetual property, interest, or privilege in the land forming the bed or shore of any water.

(2)-Subsection (1) does not affect the right of the Crown under any other Act of the Legislature to dispose of minerals in, on or under lands forming the bed or shore of any water. s. 9-No right to the permanent diversion or to the exclusive use of any water shall be acquired by any riparian owner or any other person

(a) by length of use, or

(b) otherwise than in accordance with this Act or the regulations,

unless such right is acquired by a grant made pursuant to a valid agreement or undertaking existing on the first day of April, 1931.

s. 79 (1)-The Minister may direct or order the adoption of any such measures and proceedings for promoting the bene- 
ficial use of water and for controlling and regulating the diversion and application and use thereof as he finds necessary or expedient and as are consistent with the provisions of this Act, and in particular may direct or order

(a) that gauges, weirs, meters, or other devices for water or water-power measurement be established in rivers, streams, lakes, conduits, or channels, whether natural or otherwise,

(b) that high water marks be placed on rivers, streams, lakes or other waters.

(2) - The Minister may direct or order

(a) that examinations or surveys be made

(i) of all streams, and

(ii) of the sources of water supply,

for irrigation, water-power or any other purposes.

Water Users' Districts Act.

1955 R.S.A. c. 363 .

Wills Act.

1960 S.A. c. 118.

Workmen's Compensation Act. 1955 R.S.A. c. 370. s. 3-When owners of at least half of any tract of land within an irrigation district, or that is served or proposed to be served by an irrigation system belonging to any corporation or person, desire that such tract be formed into a district and that the owners thereof be formed into a water users' association governed by a board of managers and with the privileges, rights and duties hereinafter set out, the owners shall proceed as is hereinafter prescribed.

s. 13-A rate so imposed constitutes a debt due from the person upon whom it is imposed to the managers and may be recovered by action or distraint in the same manner as a municipal tax is recoverable under the provisions of The Municipal District Act.

s. 26-Except when a contrary intention appears by the will, where real property is devised to a person without words of limitation, the devise passes the fee simple or the whole of any other estate that the testator had power to dispose of by will in the real property.

s. 77 (4)-Notwithstanding anything contained in any other Act, the amount due to the Board by an employer upon any assessment made under this Act or in respect of any amount that the employer is required to pay to the Board under any of the provisions of this Act or upon any judgment for such assessment or amount, is a charge upon the property of the employer, including moneys payable to, for, or on account of the employer, within the Province.

(5) Such charge has priority over all debts, liens, charges, mortgages or other encumbrances, whatsoever, whenever created, except wages due to employees by their employer or employers in cases where the exercise of the priority would deprive the claimant thereafter of such wages.

(6)-Any real estate of an employer is bound, to the same extent as by a registered judgment or mortgage, by any assessment made under this Act against the employer from the date of the lodging of a certified statement of the moneys due to the Board for assessment or otherwise in the land titles office for the district in which the real estate is situated, and any judgment entered with respect to the statement binds the property from the date of the lodging of the statement so certified.

(7)-The Registrar of such land titles office shall record such statement. 